\title{
TAMNA I SVIJETLA STRANA TAMNE BROJKE KRIMINALA: O IZAZOVIMA ISTRAŽIVANJA NEPOZNANICA I BLAGOSLOVU NEZNANJA
}

Izv. prof. dr. sc. Anna-Maria Getoš Kalac*

Dalia Pribisalić, mag. psych.**
UDK: 343.9:311.312(497.5)

343.97497.5)

DOI: 10.3935/zpfz.70.5.03

Izvorni znanstveni rad

Primljeno: rujan 2020.

Autori u radu na temelju recentnih međunarodnih, inozemnih i domaćih istraživanja kritički analiziraju postojeće spoznaje o tamnoj brojci kriminala i u njima utkane konceptualne te metodološke izazove radi upućivanja ne samo na uobičajeno isticanu tатпи stranu tamne brojke kriminala, već i radi zaključnog osvještavanja njezine, gotovo u cijelosti zanemarene, svijetle strane. U tom se smislu svijetla strana tamne brojke kriminala odnosi na tezu o tzv. preventivnom učinku neznanja (njem. Präventivwirkung des Nichtwissens) te predstavlja fenomen koji ima iznimno važnu, a u domaćem kriminološkom i kaznenopravnom diskursu potpuno zanemarenu pozitivnu funkciju održavanja predodžbe o obuhvatnosti i učinkovitosti kaznenog progona, a bez te predodžbe zamišljeni generalno preventivni učinak kaznenoga prava postaje bespredmetan. Time autori s jedne strane teže ostvarivanju znanstvenog doprinosa sveobuhvatnosti diskursa o tamnoj brojci i kriminalu u Hrvatskoj, dok s druge strane upućuju na nesavladive konceptualne te gotovo neotklonjive metodološke izazove pri pokušajima rasvjetljavanja tamne brojke kriminala. Namjera autora nije niti devalvacija (srozavanje vrijednosti) istraživanja tamne brojke općenito, niti se potiče rezignacija (odustajanje) u naumu rasvjetljavanja tamne brojke pojedinih skupina delikata pomoću viktimizacijskih i samoiskaznih studija. Namjera je autora sveobuhvatno $i$ kritičko sagledavanje fenomena tamne brojke kriminala $u$

* Dr. sc. Anna-Maria Getoš Kalac, LL.M., izvanredna profesorica Pravnog fakulteta Sveučilišta u Zagrebu, Trg Republike Hrvatske 14, Zagreb; agetos@pravo.hr; ORCID ID: orcid.org/0000-0002-0016-764X

** Dalia Pribisalić, mag. psych., asistentica Pravnog fakulteta Sveučilišta u Zagrebu (Violence Research Lab), Trg Republike Hrvatske 14, Zagreb; dpribisalic@pravo.hr; ORCID ID: orcid.org/0000-0001-5155-9793 
svoj svojoj složenosti, životnosti $i$ međusobnoj isprepletenosti s akterima kaznenog progona, pri tome ne podcjenjujući njezine negativne spoznajne učinke, ali isto tako ni ne zanemarujući njezinu nadasve pozitivnu funkciju u službi stabilizacije normi i održivosti represivnog sustava te društva u cjelini.

Ključne riječi: tamna brojka kriminala, viktimizacijske studije, mjerenje kriminala, studije samoiskazane delinkvencije

\section{UVOD***}

Fenomen tamne brojke kriminala, koji obuhvaća sva ona kažnjiva ponašanja koja su se ostvarila, no nisu registrirana od strane mjerodavnih državnih tijela, dobro je poznat problem u kriminologiji. ${ }^{1}$ Učestalo isticana problematičnost tamne brojke kriminala ima praktičnu, ali i znanstveno-istraživačku dimenziju. Praktična se dimenzija problema ponajprije dovodi u vezu s izostankom očekivane represivne (te u smislu recidivizma i preventivne) reakcije tijela kaznenog progona, zbog čega je počiniteljima uskraćena primjerena kazna (i tretman), a (konkretnim i budućim) žrtvama uskraćena je pomoć i zaštita, dok društvo u cjelini trpi nekažnjeno nepoštovanje normi. Znanstveno-istraživačka dimenzija problema tamne brojke se pak u svojoj biti svodi na nepotpuno poznavanje fenomenologije i etiologije kriminala zbog čega kriminološke spoznaje ostaju fragmentarne i u većoj ili manjoj mjeri spekulativne. ${ }^{2}$ Navedenu spekulativnost kriminoloških spoznaja koje se temelje na službenim statistikama o registriranom kriminalu kriminologija nastoji ublažiti istraživanjima tamne brojke. No, kako i ona pate od vlastitog problema tamne brojke, što zbog konceptualnih, što zbog metodoloških izazova, jasno je kako je zapravo riječ o kriminološkom problemu

*** Ovaj rad napisan je u okviru projekta CroViMo, koji sufinanciraju Hrvatska zaklada za znanost i Pravni fakultet Sveučilišta u Zagrebu. Vidi opširnije na: www.violence-lab.eu (25. rujna 2020.).

1 Kovanje pojma tamne brojke (njem. Dunkelziffer; engl. dark figure of crime) pripisuje se japanskom studentu kriminologije Shigemu Obi, koji je produkt tradicije njemačke moralne statistike. Vidi: Oba, S., Unverbesserliche Verbrecher und ihre Behandlung, Hermann Bahr, Berlin, 1908., prema: de Castelbajac, M., Brooding Over the Dark Figure of Crime: The Home Office and the Cambridge Institute of Criminology in the Run-up to the British Crime Survey, The British Journal of Criminology, vol. 54, br. 5, 2014., str. 930; Kivivuori, J., Discovery of Hidden Crime, Self-Report Delinquency Surveys in Criminal Policy Context, Oxford University Press, Oxford, 2011., str. 42.

2 O nedostacima službenih statistika kojima se bilježi registrirani kriminal vidi primjerice: Ariel, B.; Bland, M., Is Crime Rising or Falling? A Comparison of Police-Recorded Crime and Victimization Surveys, u: Deflem, M.; Silva, D. M. D. (ur.), Methods of Criminology and Criminal Justice Research, Sociology of Crime, Law and Deviance, vol. 24, Emerald Publishing Limited, Howard House, 2019., str. 7 - 31. 
par excellence. Stoga ne iznenađuje što se tamna brojka kriminala i u praksi i u znanosti pretežito doživljava i tretira kao problem koji valja riješiti i kao fenomen s izrazito negativnim predznakom. No, je li uistinu tako? Trebamo li doista i u praksi i u znanosti, ali i kao društvo u cjelini, fenomen tamne brojke kriminala doživljavati isključivo kao svojevrsno prokletstvo, ili bismo ga pak istovremeno te sa određenom dozom zahvalnosti trebali prigrliti kao blagoslov neznanja?

Iako na prvi pogled prilično paradoksalno, tamna brojka kriminala zaista osim netom prikazane tamne strane ima i svijetlu stranu. Osvještavanje pozitivne funkcije te svijetle strane tamne brojke od presudne je važnosti i za kaznen(opravn)u praksu i za znanost, a posebno za javni diskurs o kriminalu, u kojemu se nerijetko artikulira zgražanje nad pretpostavljenom količinom neotkrivenog i neprocesuiranog kriminala. No, što bi se zapravo dogodilo $\mathrm{u}$ društvu u kojemu ne bi postojala tamna brojka kriminala, odnosno kakvo bi to bilo društvo u kojemu je moguća detekcija svakog kažnjivog ponašanja i bismo li takvom društvu uopće trebali težiti? ${ }^{3}$ To su samo neka pitanja na koja ćemo nastojati odgovoriti, no već u ovom uvodnom dijelu valja istaknuti kako potpuno rasvjetljavanje tamne brojke kriminala, osim što je utopija, nije nešto čemu bi bilo koje društvo trebalo težiti.

\section{PREGLED GLAVNIH ISTRAŽIVANJA TAMNE BROJKE KRIMINALA}

Imajući na umu netom spomenutu važnost poznavanja tamne brojka kriminala za razumijevanje fenomenologije i etiologije kažnjivih ponašanja, brojnost i kvaliteta kriminoloških istraživanja kojima se nastoji rasvijetliti tamna brojka zapravo su iznenađujuće niske. Dok na međunarodno komparativnoj i inozemnoj razini još i nalazimo recentne te konceptualno i metodološki solidno razrađene studije ovog tipa, u domaćem okružju uočavamo ozbiljan deficit usporedivih studija. Taj deficit posebno je izražen kada je riječ o istraživanjima tamne brojke kriminala općenito, dok je situacija kada su u pitanju pojedini fenomenološki tipovi kažnjivih ponašanja nešto povoljnija. Pri tome i ono malo domaćih istraživanja što postoji u dobrom dijelu slučajeva zapravo predstavlja nacionalne komponente velikih međunarodnih studija. Takva situacija, iako deficitarna, nimalo ne iznenađuje osvijestimo li činjenicu da je kriminologija u Hrvatskoj,

3 O vezanoj problematici transformacije klasičnog post-crime u aktualno pre-crime društvo te posljedičnim implikacijama za kriminologiju i kazneno pravo vidi opširnije: Getoš Kalac, A.-M., Guilt, Dangerousness and Liability in the Era of Pre-Crime - the Role of Criminology? To Adapt, or to Die, that is the Question!, Monatschrift für Kriminologie und Strafrechtsreform, vol. 103, br. 3, 2020., str. 198 - 207. 
unatoč svojoj dugoj institucionalnoj povijesti koja usporedno sa samim začecima kriminologije počinje već rane 1905. godine na Pravnom fakultetu Sveučilišta u Zagrebu, u sadržajnom smislu do unatrag nekoliko godina vodila prilično isprazan život s razmjerno slabom znanstvenom produkcijom vlastitih i originalnih spoznaja (u usporedbi s drugim europskim državama). ${ }^{4}$ Stoga je i analiza istraživanja kojima se nastoji rasvijetliti fenomen tamne brojke kriminala, kako je prikazana u nastavku, u najvećem dijelu usredotočena na spoznaje proizašle iz međunarodnih komparativnih i inozemnih studija, dok su tek primjera radi izdvojene neke od glavnih spoznaja relevantnih domaćih studija.

\subsection{Međunarodne komparativne studije}

Glavni je cilj međunarodnih kriminoloških komparativnih studija stvaranje pouzdanih baza podataka koje je moguće uspoređivati neovisno o tome kako pojedine države kaznenopravno tretiraju različite pojavne oblike kažnjivih ponašanja. Čak i zanemarujući specifične izazove tamne brojke kriminala, sama međunarodna komparacija službenih statistika registriranog kriminala iznimno je izazovna i u konceptualnom i u metodološkom pogledu. ${ }^{5}$ Osim brojnih izazova

4 Vidi opširnije u: Getoš Kalac, A.-M.; Bezić, R., Criminology, crime and criminal justice in Croatia, European Journal of Criminology, vol. 14, br. 2, 2017., str. 242 - 266; Getoš, A.-M., Mjesto i uloga kriminologije i viktimologije u Hrvatskoj i u međunarodnom kontekstu, u: Turković, K.; Maršavelski, A.; Roksandić Vidlička, S. (ur.), Liber Amicorum Zvonimir Šeparović: Od kaznenog prava do viktimologije, Zbornik radova u čast 80. rođendana profesora emeritusa Zvonimira Šeparovića, Pravni fakultet Sveučilišta u Zagrebu, Zagreb, 2009., str. 119 - 140. No, ako hrvatsku kriminologiju umjesto u zapadnoeuropski smjestimo u jugoistočnoeuropski kontekst, onda uočavamo da spomenuti deficit nije ekskluzivno hrvatska, već zapravo regionalna karakteristika kriminologije kao relativno mlade znanstvene discipline. Iscrpno o kriminološkom krajoliku Balkana u: Getoš Kalac, A.-M., Mapping the Criminological Landscape of the Balkans, u: Getoš Kalac, A.-M.; Albrecht, H.-J.; Kilchling, M. (ur.), Mapping the Criminological Landscape of the Balkans, A Survey on Criminology and Crime with an Expedition into the Criminal Landscape of the Balkans, Max-Planck-Gesellschaft zur Förderung der Wissenschaften e.V. in coop. with University of Zagreb - Faculty of Law and Duncker \& Humblot, Berlin, 2014., str. 23 - 55.

5 Ni na međunarodnoj ni na europskoj razini nije moguće u cijelosti uskladiti statistike o kriminalu, iako su praktična i znanstvena nastojanja na tom polju zbilja zadivljujuća. Usporedi United Nations Office on Drugs and Crime, International Classification of Crime for Statistical Purposes, Version 1.0, United Nations Office on Drugs and Crime, Beč, 2015.; European Union, EU guidelines for the International Classification of Crime for Statistical Purposes - 2017 edition, Publications Office of the European Union, Luxembourg, 2017.; Aebi, M. et al., European Sourcebook of Crime 
s kojima se nose međunarodne statistike kriminala, studije kojima se nastoji rasvijetliti tamna brojka suočene su s nizom dodatnih izazova. No, o tome će biti više govora u trećem dijelu ovog rada. Zasad je bitno istaknuti dva ključna pitanja na koja istraživanja tamne brojke kriminala nastoje odgovoriti:" l) u kojoj mjeri službene statistike o registriranom kriminalu odgovaraju realnom stanju kriminala, i 2) koji su razlozi neprijavljivanja i/ili izostanka detekcije kažnjivih ponašanja. Izvori podataka putem kojih je moguće odgovoriti na ova pitanja su (pretpostavljene) žrtve kažnjivih ponašanja te (pretpostavljeni) počinitelji, stanovništvo općenito u svojoj funkciji (pretpostavljenih) svjedoka, eksperti i praktičari uključeni u ili vezani uz kazneno pravosuđe (u najširem smislu), ali i široki krug profesionalaca koji kroz svoj rad ili često dolazi u kontakt s potencijalnim žrtvama i/ili počiniteljima kažnjivih ponašanja (npr. medicinsko osoblje), ili radi s posebno ranjivim skupinama potencijalnih žrtava (npr. odgajatelji u predškolskim ustanovama ili pedagozi/psiholozi u školama). Slijedom toga razlikujemo tzv. viktimizacijske studije (engl. victimisation survey), u kojima ispitanici daju podatke o vlastitom iskustvu viktimizacije, zatim tzv. samoiskazne studije o vlastitom delinkventnom ponašanju ispitanika (engl. self-report survey) te niz tematskih kriminoloških istraživanja, koja iako se težišno bave drugim temama (npr. osjećaj sigurnosti i strah od kriminala ili percepcija korupcije), u pojedinim segmentima ispituju viktimizaciju i/ili delinkventno ponašanje ispitanika, ali i njihovo (ne)prijavljivanje kažnjivih ponašanja, odnosno (ne) otkrivenost te doticaj ispitanika s tijelima kaznenog progona. ${ }^{7}$

and Criminal Justice Statistics 2014 Fifth edition 2nd revised printing, European Institute for Crime Prevention and Control HEUNI, Helsinki, 2017.

6 Naravno, osim navedenih specifičnih pitanja u odnosu na tamnu brojku kriminala, sva kriminološka istraživanja u biti teže rasvjetljavanju fenomenologije i etiologije kažnjivih ponašanja općenito ili pak u odnosu na pojedine promatrane skupine delikata, počinitelja i/ili žrtava u određenom vremenskom i prostornom kontekstu.

$7 \quad$ Kao primjer takvih međunarodnih istraživanja, koja tematski nisu usredotočena na tamnu brojku kriminala, ali ipak prikupljaju i analiziraju podatke o viktimizaciji ispitanika i njihovu delinkventnom ponašanju, moguće je navesti studije straha od kriminala i stavova prema kažnjavanju. Vidi primjerice: Kury, H.; Winterdyk, J. (ur.), Fear of Crime and Punitiveness: Results from International Student Surveys, Universitätsverlag Brockmeyer, Bochum, 2013. te nalaze istraživanja provedenog u Hrvatskoj u: Getoš, A.-M.; Giebel, S., Perceptions of fear of crime and punitivity among university students in Croatia, u: Kury, H.; Winterdyk, J. (ur.), Fear of Crime and Punitiveness: Results from International Student Surveys, Universitätsverlag Brockmeyer, Bochum, 2013., str. 105 - 138 ili Getoš, A.-M.; Giebel, S., Strah od kriminala među studentima Pravnog fakulteta u Splitu, Zbornik radova Pravnog fakulteta u Splitu, vol. 49, br. 3, 2012., str. 533 - 552. 
Najpoznatija viktimizacijska studija je Međunarodno istraživanje kriminalne viktimizacije (engl. International Crime Victimization Survey; ICVS ${ }^{8}$ ). Riječ je o jednom od glavnih izvora kriminoloških i viktimoloških spoznaja posljednjih nekoliko desetljeća. Osvrćući se tako na podatke prikupljene 2005. godine, Van Dijk, Van Kesteren i Smit navode kako se tek trećina ostvarenih kažnjivih ponašanja s elementima nasilja i prijetnje prijavljuje nadležnim institucijama, dok se kaznena djela protiv imovine gotovo uvijek i u većini ispitanih država prijavljuju policiji. ${ }^{9}$ ICVS rezultati također pokazuju kako je najveća tamna brojka kod seksualnih delikata, od kojih čak 85 \% ostaje neprijavljeno, dok se tamna brojka kod najtežih seksualnih delikata poput silovanja nešto smanjuje, ali i dalje iznosi visokih $77 \% .{ }^{10}$ Nadalje, autori komparativnom analizom kaznenih djela krađe automobila i bicikla, pokušanim i dovršenim provalama te krađom privatne imovine pronalaze manju tamnu brojku u ekonomski najrazvijenijim državama svijeta kao što su Austrija, Belgija, Švedska i Švicarska, dok veću tamnu brojku bilježe u slabije razvijenim državama poput Brazila, Perua, Meksika i Kambodže. ${ }^{11}$ Uzimajući u obzir nepovoljnije opće društveno-ekonomsko stanje u navedenim državama i izraženiju prevalenciju kriminala u njima te učestalost neprijavljivanja ovog tipa kažnjivog ponašanja policiji jer ono "nije dovoljno ozbiljno", ovakvi rezultati mogli bi upućivati na manju sklonost prijavljivanju onih (lakših) kažnjivih ponašanja za koja stanovništvo smatra kako su "uobičajena" ili pak "manje pogubna od uobičajenih".

Kako ICVS ne uključuje podatke ispitanika mlađih od 16 godina, nastaje potreba za pokretanjem Međunarodne studije samoiskazane delinkvencije (engl. International Self-Report Delinquency Study; ISRD ${ }^{12}$ ). ISRD je u kontekstu rasprave o tamnoj brojci kriminala iznimno važan zato što službenim statistikama o registriranom kriminalu djeca (zbog izostanka kaznenopravne odgovornosti) kao počinitelji u istima nisu obuhvaćana. Iako primarno usmjerena na samoiskaze o vlastitom delinkventnom ponašanju ispitanika u dobi od 12 do 16 godina, ISRD ispituje i viktimizaciju ispitanika. Enzmann i suradnici navode kako najnoviji rezultati (ISRD3 ${ }^{13}$ ) pokazuju kako se učestalost prijavljivanja krađa policiji

8 Detalji o navedenoj studiji dostupni su na: www.unicri.it (1. rujna 2020.).

9 Van Dijk, J. J. M.; Van Kesteren, J.; Smit, P., Criminal Victimisation in International Perspective, Key findings from the 2004-2005 ICVS and EU ICS, Bibliotheek WODC, Den Haag, 2007., str. 109.

10 Ibid.

11 Cf. ibid., str. 111.

12 Više informacija o ISRD studiji dostupno je na: web.northeastern.edu/isrd/ (20. kolovoza 2020.).

13 Vidi: https://web.northeastern.edu/isrd/isrd3/ (20. kolovoza 2020.). 
ne povećava proporcionalno s prevalentnošću tog kaznenog djela na nekom području ${ }^{14}$, što je u skladu s nalazima ICVS-a. Uspoređujući situaciju između pojedinih skupina država, utvrđuje se kako su ispitanici iz država s balkanskog područja (22 \%), iz zapadne Europe (19\%) te neeuropskih država (18 \%) skloniji prijavljivanju kažnjivih ponašanja policiji, dok su oni iz Sjedinjenih Američkih Država (SAD) najmanje skloni prijaviti doživljenu viktimizaciju (13 \%). ${ }^{15}$ Dok je viši stupanj doživljene viktimizacije povezan s nižim stupnjem povjerenja u policiju i njihovu legitimnost, veći stupanj povjerenja u policijske službenike ili vjere u njihovu legitimnost nije nužno povezan sa sklonošću prijavljivanja. ${ }^{16}$ Prema tome, autori uočenu razliku u sklonosti prijavljivanju kažnjivih ponašanja pripisuju razlikama (prosječne težine) slučajeva koji prevladavaju u različitim državama: manje ozbiljno doživljena kažnjiva ponašanja rjeđe će se prijaviti policiji od onih koje pojedinci percipiraju kao ozbiljnija. ${ }^{17}$

U kontekstu ISRD studije svakako valja spomenuti i BECAN epidemiološko istraživanje zlostavljanja i zanemarivanja djece ${ }^{18}$, koje je kao i ISRD3 studija $\mathrm{u}$ pogledu hrvatske komponente provedeno od strane istraživača s Pravnog fakulteta Sveučilišta u Zagrebu. ${ }^{19}$ Nalazi BECAN studije upućuju na znatno višu prevalenciju psihološkog i fizičkog nasilja nad djecom na Balkanu nego u ostatku Europe, dok je seksualno nasilje češće nad muškom djecom nego ženskom, što nije nužno u skladu s recentnim istraživanjima u ostalim europskim državama. ${ }^{20}$ No, pri usporedbi rezultata BECAN studije s nalazima drugih

14 Opširnije u: Enzmann, D. et al., A global perspective on young people as offenders and victims, Springer, Berlin, 2018., str. 45.

15 Cf. ibid., str. 47.

16 Cf. ibid., str. 53.

17 Cf. ibid., str. $50-53$.

18 Studija je provedena u devet država s područja Balkana na ukupnom uzorku od 42.194 djece u dobi od 11 do 16 godina, koja su u osnovnim/srednjim školama ispunjavala upitnik za procjenu incidencije i prevalencije zlostavljanja i zanemarivanja djece (ISPCAN Child Abuse Screening Tool - Children's Version; ICAST-C) u svrhu utvrđivanja mogućeg psihološkog, fizičkog i/ili seksualnog zlostavljanja. Vidi opis projekta: https://www.pravo.unizg.hr/istrazivanja/projekti/becan (1. rujna 2020.) i sažet pregled najvažnijih rezultata istraživanja: https://cordis.europa.eu/ project/id/223478/reporting (1. rujna 2020.).

19 Vidi opširnije: https://web.northeastern.edu/isrd/croatia/ (14. rujna 2020.).

20 Dok se u balkanskim državama postotak djece koja su doživjela psihološko nasilje javlja u rasponu od $65 \%$ do $83 \%$, a fizičko od $51 \%$ do $76 \%$, u ostatku Europe prosječno 30 \% djece doživljava neki oblik psihološkog, a 23 \% fizičkog nasilja. Iako je veći broj recentnih studija u Europi ustanovio kako djevojčice (14 \%) doživljavaju seksualno nasilje dvostruko češće od dječaka (6 \%), nalazi BECAN studije u poje- 
istraživanja, poput primjerice ISRD3, potreban je oprez jer se dobivene velike razlike u detektiranoj viktimizaciji mogu objasniti i širim/užim konceptualnim pristupom fenomenu nasilja te različitim definiranjem pojedinih oblika nasilja, kažnjavanja i zlostavljanja. ${ }^{21}$ Iako rezultati BECAN studije ne dovode u neposrednu vezu utvrđene razine viktimizacije s veličinom tamne brojke po pitanju

dinim balkanskim državama upućuju na obrnutu situaciju u kojoj su dječaci (8 \% - $20 \%$ izloženiji seksualnom nasilju nego djevojčice (6 \% - $18 \%)$. Vidi opširnije: Nikolaidis, G. et al., Lifetime and past-year prevalence of children's exposure to violence in 9 Balkan countries: the BECAN study, Child and adolescent psychiatry and mental health, vol. 12, br. 1, 2018., str. 12.

21 Tako se u BECAN i ISRD3 studijama primjerice različito konceptualiziraju i određuju pojmovi tjelesnog kažnjavanja i tjelesnog zlostavljanja, pri čemu ISRD3 za razliku od BECAN-a uopće ne prikuplja podatke o mogućoj izloženosti ispitanika psihičkoj agresiji te psihičkom zlostavljanju. U BECAN studiji tjelesno kažnjavanje određeno je kao "npr. šamare, čupanje za kosu, udarce po stražnjici”, dok je tjelesno zlostavljanje određeno kao "npr. udarce nogom ili udarce šakom u glavu”. ISRD3 u tom smislu ne razlikuje "kažnjavanje” od "zlostavljanja”, pri čemu bi kažnjavanje imalo (iz dječje perspektive pretpostavljenu) funkciju discipliniranja, već nasilje razlikuje prema njegovoj težini te polazi od toga kako (pretpostavljena) svrha nasilja i u jednom i u drugom slučaju može biti kažnjavanje/discipliniranje: 1. “Jesu li te ikad ... udarili, ošamarili ili odgurnuli? (Uključujući i kada je to bio oblik kažnjavanja zbog nekog tvog lošeg ponašanja.)" i 2. "Jesu li te ikada ... udarili nekim predmetom, udarili te nogom, udarili šakom ili pretukli? (Uključujući i kada je to bio oblik kažnjavanja zbog nekog tvog lošeg ponašanja.)". Iako se navedene razlike ne čine dramatičnima, dodamo li tome još i BECAN-ovo određenje psihičke agresije kao "npr. roditelj je vikao ili se derao na dijete ili je ignorirao dijete, tj. odbijao s njime razgovarati ili vrijeđao dijete nazivajući ga glupim, lijenim" te psihičkog zlostavljanja kao "npr. roditelj je rekao djetetu da bi želio da je mrtvo ili da se nikada nije rodilo ili je prijetio djetetu da će ga izbaciti iz kuće ili poslati da živi negdje drugdje”, onda ne iznenađuju dramatične razlike u nalazima jedne i druge studije. Naime, ako se pod koncept nasilja uvrsti i psihička agresija te psihičko zlostavljanje, onda u smislu izloženosti djece nasilju u obitelji prema BECAN studiji nalazimo kako je čak 65,8 \% djece u Hrvatskoj bilo izloženo nasilju u obitelji. No, pogledamo li podatke ISRD3 studije, koja izloženost djece nasilju u obitelji promatra isključivo kroz varijable tjelesnog nasilja, onda vidimo kako je detektirana viktimizacija znatno manja, iako se obje studije u pogledu tjelesnog nasilja uvelike podudaraju. Ovaj primjer zorno upućuje na dalekosežnost konceptualizacije osnovnih istraživačkih pojmova (npr. nasilje koje u svojoj biti neupitno sadržava fizičku komponentu, no ne i nužno psihičku) te posljedične izazove usporedbe i interpretacije nalaza proizašlih iz različitih studija, koje se provode gotovo istovremeno, na usporedivoj populaciji te od strane istraživača s iste ustanove. Usporedi Ajduković, M.; Ogresta, J.; Sušac, N., Prikaz konferencije Raširenost nasilja nad djecom u obitelji i među vršnjacima, Ljetopis socijalnog rada, vol. 19, br. 1, 2012., str. 183; Bezić, R., Juvenile Delinquency in the Balkans: A Regional Comparative Analysis Based on the ISRD3-Study Findings, Max-Planck-Gesellschaft zur 
zlostavljanja djece, omogućuju kao i oni proizašli iz ISRD3 izvrstan uvid u rasprostranjenost i učestalost različitih oblika nasilja nad djecom na području Balkana. Time su stvoreni solidni temelji za buduća istraživanja.

Od ključnih novijih međunarodnih komparativnih viktimoloških istraživanja svakako treba spomenuti i istraživanje nasilja nad ženama, koje provodi Agencija za temeljna prava Europske unije (engl. European Union Agency for Fundamental Rights; FRA). ${ }^{22}$ Iako je za razliku od vrlo široko i općekriminološki postavljenih ICVS i ISRD studija ovdje riječ o tematski usko fokusiranom istraživanju viktimizacije žena i njihove izloženosti nasilju, u nedostatku redovitih europskih općih viktimizacijskih studija, ona pruža vrijedne spoznaje o tamnoj brojci nasilnih i seksualnih delikata diljem Europe. Rezultati istraživanja pokazuju kako su žene nešto sklonije prijaviti fizičko i/ili seksualno nasilje počinjeno od strane partnera (33\%) nego od strane osobe s kojom nisu nikada bile u vezi $(26 \%)^{23}$, pri čemu su u oba slučaja sklonije prijaviti seksualno negoli fizičko nasilje. ${ }^{24}$ Zanimljivo je i kako su žrtve sklonije nasilje prijaviti medicinskom osoblju (19 \% fizičko, 27 \% seksualno nasilje), dok su policijski službenici tek na drugome mjestu. ${ }^{25}$ Pri tome se prijavljivanje policiji ne razlikuje značajno s obzirom na to je li riječ o fizičkom ili seksualnom nasilju te postoji li intimna veza između žrtve i počinitelja. ${ }^{26}$ Iako se razlozi neprijavljivanja seksualnog i/ili fizičkog nasilja razlikuju s obzirom na odnos između žrtve i počinitelja, u oba slučaja žrtve kao razlog navode kako "su problem htjele riješiti same ili uz pomoć obitelji i prijatelja" ili kako djelo "ne zahtijeva pomoć policije". ${ }^{27}$ Žrtve seksualnog nasilja dodatno navode "sram” i “želju da nitko ne sazna za

Förderung der Wissenschaften e.V. in coop. with University of Zagreb - Faculty of Law and Duncker \& Humblot, Berlin, u tisku 2020.

22 Opširnije: European Union Agency for Fundamental Rights, Violence against women, An EU-wide survey: main results, Publications Office of the European Union, Luxembourg, 2015., str. 59 - 66. Riječ je o studiji provedenoj u 28 država članica Europske unije na uzorku od ukupno 42.000 žena u dobi od 18 do 74 godina, s 1500 slučajno odabranih žena po državi s kojima su provedeni intervjui licem u lice. Vidi sažet pregled najvažnijih rezultata: Till-Tentschert, U., FRA's work on gender based violence, European Union Agency for Fundamental Rights, Prag, 14. studenog 2017.

23 Cf. ibid., str. 60.

24 U slučajevima gdje je počinitelj trenutačni ili bivši partner žrtve 39 \% žena izjavilo je kako bi prijavile seksualno nasilje, dok bi fizičko nasilje prijavilo svega 31 \%. $\mathrm{S}$ druge strane, u slučajevima u kojima počinitelj nije partner, seksualno nasilje prijavilo bi 31 \% žena, a fizičko tek $24 \%$ ispitanica. Cf. ibid., str. 59.

25 Cf. ibid., str. 60.

26 Ibid.

27 Cf. ibid., str. 63. 
događaj" kao razlog neprijavljivanja te "neznanje kome se obratiti". ${ }^{28} \mathrm{~S}$ druge strane, žrtve fizičkog nasilja sklonije su nasilje smatrati "nedovoljno bitnim" za prijavu, pa fizičko nasilje prijavljuju tek kada je "dovoljno ozbiljno". ${ }^{29}$ Važno je napomenuti kako su žrtve koje jesu prijavile nasilje najmanje zadovoljne bile s reakcijom policije, usporedno s drugim institucijama poput bolnica, liječnika opće prakse ili drugih organizacija, a žrtve seksualnog nasilja bile su manje zadovoljne od onih koje su pretrpjele fizičko nasilje. ${ }^{30} \mathrm{U}$ svakom slučaju rezultati studije potvrđuju iznimno visoku tamnu brojku u sferi fizičkog i seksualnog nasilja nad ženama diljem Europe. ${ }^{31}$

Na kraju valja spomenuti i europsku viktimizacijsku studiju (engl. European Crime and Safety Survey; EU ICS), provedenu 2005. godine. ${ }^{32}$ Osim proučavanja doživljene viktimizacije po uzoru na ICVS, EU ICS-om ispitan je i odnos sudionika prema policiji, prevenciji kriminala te osjećaju sigurnosti. ${ }^{33}$ Slično kao i kod drugih studija ovog tipa, rezultati EU ICS-a upućuju na utjecaj vrste kaznenog djela na tamnu brojku. Dok ispitanici navode kako gotovo sve krađe (iz) motornih vozila i provale prijavljuju policiji, svega svaki drugi fizički napad prijavljuju (45\%), a ni trećina seksualnih napada ne bude prijavljena (28\%), s time da se od težih seksualnih incidenata prijavi tek svaki sedmi $(15 \%) \cdot{ }^{34} \mathrm{Kao}$ najčešći razlog neprijavljivanja viktimizacije mjerodavnim tijelima sudionici

28 Ibid.

29 Cf. ibid., str. 60.

30 Cf. ibid., str. 64.

31 Za pregled podataka o viktimizacijskim iskustvima žena u Hrvatskoj i u kontekstu podataka o (registriranom) kriminalu vidi primjerice: Getoš Kalac, A.-M.; Roksandić Vidlička, S.; Burić, Z., Victimology, Victimisation (Typology) \& Victim Protection in Croatia, u: Meško, G.; Sárik, E.; Getoš Kalac, A.-M. (ur.), Mapping the Victimological Landscape of the Balkans: A Regional Study on Victimology and Victim Protection with a Critical Analysis of Current Victim Policies, Max-Planck-Gesellschaft zur Förderung der Wissenschaften e.V. in coop. with University of Zagreb - Faculty of Law and Duncker \& Humblot, Berlin, 2020., str. 223 - 276.

32 Institucije uključene u provedbu studije: Gallup Organisation Europe, The United Nations Interregional Crime and Justice Research Institute (UNICRI), Max Planck institut za inozemno i međunarodno kazneno pravo, Luxembourg Institute of Socio-Economic Research (LISER) te GeoX Hungary.

33 United Nations Interregional Criminal Justice Research Institute, EU ICS Working Paper Series: Methodology of the European Crime and Safety Survey, Gallup Europe, Bruxelles, 2007., str. 3.

34 Usporedi Van Dijk, J. J. M. et al., The burden of crime in the EU: A comparative analysis of the European Survey of Crime and Safety (EU ICS 2005), Gallup Europe, Bruxelles, 2007., str. 68. 
navode "trivijalnost" delikta te "samostalno rješavanje problema"35, nalaz koji se provlači kroz sve viktimizacijske studije i istraživanja tamne brojke.

Zaključno treba istaknuti kako se učestalo vode stručne i znanstvene rasprave te svako toliko pokreću inicijative za redovito provođenje nacionalnih viktimizacijskih studija diljem Europe s ciljem rasvjetljavanja tamne brojke i stjecanja potpunijih spoznaja o realnom stanju kriminala. No, u ekspertnim krugovima može se čuti kako zbog nesuglasica o konkretnim institucionalnim nositeljima na europskoj razini te izvorima financiranja takve studije do sada nije bilo moguće organizirati redovito provođenje Europske viktimizacijske studije. ${ }^{36}$ Može se pretpostaviti kako se navedene nesuglasice (kao i do sada) neće u skorijoj budućnosti razriješiti, tako da će i dalje ICVS, ISRD, FRA studija o nasilju nad ženama ${ }^{37}$ i viktimizacijske studije fokusirane na posebno ranjive skupine žrtava (npr. BECAN), zajedno sa sporadičnim viktimološkim nalazima drugih kriminoloških studija (npr. istraživanje straha od kriminala i osjećaja sigurnosti među građanima), činiti glavninu spoznajnih izvora o realnom stanju kriminala, pa samim time i o njegovoj tamnoj brojci.

\subsection{Inozemna istraživanja}

U skladu s nalazima međunarodnih studija i brojna (nacionalna) inozemna istraživanja, poput primjerice onoga provedenog 2012. godine u Južnoafričkoj Republici (JAR), upućuju na veliku tamnu brojku upravo kod onih kažnjivih ponašanja koja pojedinci smatraju “trivijalnim” (npr. krađe). ${ }^{38}$ No, nije samo procijenjena "trivijalnost" delikta razlog neprijavljivanja kažnjivih ponašanja, što se zorno ogleda u visokoj tamnoj brojci kod nasilnih delikata u SAD-u. Tamošnje viktimizacijske studije (engl. National Crime Victimisation Study:

35 Cf. ibid., str. 70.

36 Tako je u više navrata raspravljano u okviru rada Ekspertne skupine za tzv. European Sourcebook of Crime and Criminal Justice Statistics (ESB). Vidi opširnije: https://wp.unil.ch/europeansourcebook/european-sourcebook-members/group-ofexperts/ (1. rujna 2020.).

37 Prema neslužbenim informacijama iz Državnog zavoda za statistiku Republike Hrvatske priprema se novi krug istraživanja nasilja od strane FRA-a u državama članicama Europske unije, s time da bi ono sada trebalo obuhvatiti i ispitanike muškog spola, što je i konceptualno i metodološki gledano zamjetan propust prethodno provedene viktimizacijske studije, posebice jer ispituje viktimizaciju ispitanika i u djetinjstvu.

38 Doorewaard, C., The dark figure of crime and its impact on the criminal justice system, Acta Criminologica: Southern African Journal of Criminology, vol. 27, br. 2, 2014., str. 7. 
NCVS $^{39}$ ) pokazuju kako ni polovica (43\%) nasilnih delikata u 2018. godini nije bila prijavljena policiji. ${ }^{40}$ Razlozi neprijavljivanja nasilja uključuju "bespotrebno uvlačenje počinitelja u nevolju", "nepovjerenje u to da policija može bilo što napraviti” te doživljaj kaznenog djela kao "problema žrtve" ${ }^{41}$ Čini se kako sve žrtve kažnjivih ponašanja (svjesno ili nesvjesno) procjenjuju "isplativost" prijavljivanja kaznenog djela. ${ }^{42}$ Drugim riječima, prijava krađe bit će češća od prijave zlostavljanja jer u slučaju krađe pojedinac ima mogućnost povrata novca ili stvari koja mu je ukradena, dok je u slučaju zlostavljanja proces sekundarne viktimizacije kroz koji će pojedinac vjerojatno morati proći traumatičan, a slučaj često teško dokaziv, što će sve skupa rezultirati time da će prijava nasilnog delikta biti znatno manje izgledna, bez obzira na to što je nasilni delikt sam po sebi "teži". ${ }^{43}$ Dovedemo li tezu o cost-benefit kalkulacijama žrtava u vezu s nalazima istraživanja koja upućuju na važnost povjerenja u sposobnost nadležnih tijela kaznenog progona, poput onog provedenog u Ujedinjenom Kraljevstvu i Walesu ${ }^{44}$, koji pronalaze korelaciju između povjerenja u policiju sa spremnošću stanovništva na suradnju, jasno je kako odluka o (ne)prijavljivanju kaznenog djela uvelike ovisi i o povjerenju u policiju. Takav nalaz potvrđuje spomenuto istraživanje provedeno u JAR-u, u kojemu ispitanici kao glavni razlog nepovjerenja u policiju navode "korupciju" i "primanje mita". ${ }^{5}$

Kao još jedan od razloga neprijavljivanja kažnjivih ponašanja policiji navodi se i strah žrtve od osvete počinitelja. ${ }^{46}$ Taj je problem posebno izražen u kontroliranim institucionalnim uvjetima i ustanovama poput zatvora, gdje nema jasne procedure prijave nasilja, što doprinosi visokoj tamnoj brojci fizičkog nasilja među zatvorenicima te nad zatvorskim čuvarima i od strane zatvorskih čuvara ${ }^{47}$, dok ujedno upozorava na ranjivu skupinu (skrivenih) žrtava unutar zatvora i

39 Vidi opširnije: https://www.bjs.gov/index.cfm?ty=dcdetail\&iid=245 (10. kolovoza 2020.).

40 Morgan, R. E.; Oudekerk, B. A., Criminal Victimization 2018, U.S. Department of Justice, Office of Justice Programs, Bureau of Justice Statistics, s. l., 2019., str. 6.

${ }^{41}$ Cf. ibid., str. 8.

42 Bowles, R.; Reyes, M. G.; Garoupa, N., Crime reporting decisions and the costs of crime, European journal on criminal policy and research, vol. 15, br. 4, 2009., str. 367.

43 Cf. ibid., str. 366.

44 Jackson, J. et al., Just authority? Trust in the police in England and Wales, Routledge, Abingdon, 2012., str. 145.

45 Doorewaard, op. cit. u bilj. 38, str. 6.

46 Vidi: Penney, T. L., Dark figure of crime (problems of estimation), The encyclopedia of criminology and criminal justice, John Wiley \& Sons, Inc., Hoboken, 2014., str. 3.

47 Ibid. 
sličnih zatvorenih institucija. Za područje SAD-a važno je spomenuti i visoku tamnu brojku tzv. kriminala bijelog ovratnika. Ova vrsta delikata najčešće se procesuira privatnim (građanskim) tužbama, pa stoga takvi delikti ni ne ulaze u službene statistike o (registriranom) kriminalu, ili ih organizacije pak ciljano prikrivaju u svrhu očuvanja svojeg poslovnog ugleda. ${ }^{48}$

Svakako je potrebno istaknuti i problem “začaranog kruga” nevidljivih žrtava. Naime, rezultati istraživanja koji upućuju na veliku sličnost među prediktorima viktimizacije i sklonosti prijavljivanju doživljene viktimizacije policiji pokazuju kako su najugroženije žrtve ujedno i one koje su najmanje sklone prijaviti viktimizaciju policiji. ${ }^{49}$ Takvi su nalazi zabrinjavajući već sami po sebi, ali još i više kada uzmemo u obzir kako su pojedinci koji žive u područjima koja su visoko opterećena kriminalom najmanje skloni prijavljivanju kažnjivih ponašanja, što u konačnici dovodi do toga da vlasti nisu uopće upoznate s realnom kriminalnom opterećenošću takvih mikrolokacija te posljedično ne poduzimaju odgovarajuće mjere suzbijanja kriminala i poboljšanja situacije u takvim "lošim četvrtima" ${ }^{50}$

Zaključno valja napomenuti kako u našem, europskom kontekstu većina drŽava ili periodično redovito ili jednokratno ad hoc provodi viktimizacijske studije i/ili istraživanja tamne brojke, kako u odnosu na opće stanje kriminala, tako i u odnosu na specifične vrste kriminala te posebno ranjive skupine žrtava. ${ }^{51}$ Kao što ćemo vidjeti u nastavku, Hrvatska, ali i druge države jugoistočne Europe u tom smislu odskaču od europskog konteksta jer su viktimizacijske studije i/ili istraživanja tamne brojke, pogotovo provedena od strane državnih institucija, prije iznimka negoli pravilo.

48 Podgor, E. S.; Israel, J. H., White collar crime in a nutshell, 4th Edition, West Academic Publishing, St. Paul, 2009., str. 1 - 15.

49 Fohring, S., Putting a Face on the Dark Figure: Describing Victims Who Don't Report Crime, Temida, vol. 17, br. 4, 2014., str. 12.

50 Cf. ibid., str. 14.

51 Tako primjerice Savezna Republika Njemačka redovito i na saveznoj razini i na razini saveznih država provodi viktimizacijske studije. Za saveznu razinu vidi primjerice: www.bka.de/DE/UnsereAufgaben/Forschung/ForschungsprojekteUndErgebnisse/ Dunkelfeldforschung/dunkelfeldforschung_node.html (1. rujna 2020.), a za razinu saveznih država vidi primjerice: www.lka.polizei-nds.de/forschung/dunkelfeldstudie/vierte-befragung-von-40000-buergerinnen-und-buergern-steht-unmittelbar-bevor-114474.html (1. rujna 2020.). 


\subsection{Domaća istraživanja}

Iako su domaća istraživanja o tamnoj brojci kriminala na području Hrvatske malobrojna, moguće je utvrditi okvirno stanje zahvaljujući ranom uključivanju Hrvatske u međunarodne viktimizacijske studije. Hrvatska je do sada sudjelovala u dvjema viktimizacijskim studijama u sklopu ICVS-a, i to 1996. i 2000. godine, a počevši s trećim krugom, odnosno od 2012. godine, Hrvatska uspješno sudjeluje i u ISRD-u ${ }^{52}$, participirala je u FRA studiji o nasilju nad ženama, BECAN-u te nizu međunarodnih kriminoloških studija koje se težišno ili makar djelomično bave samodoživljenom viktimizacijom i/ili samoiskazima o vlastitom delinkventnom ponašanju. ${ }^{53}$ Prvo istraživanje tamne brojke kriminala na području Hrvatske provedeno je 1982. godine, pod vodstvom Zvonimira Šeparovića, prema kojem je tadašnja situacija u Hrvatskoj procijenjena u skladu s međunarodnim istraživanjima u kojima se lakša kaznena djela prijavljuju rjeđe nego ona teža, a kao najčešći razlog neprijavljivanja navodi se da "policija ne može ništa napraviti". 54

Prema rezultatima FRA studije Hrvatska je jedna od sigurnijih država u odnosu na ostatak država članica Europske unije kad je riječ o nasilju nad ženama $^{55}$, a žene u Hrvatskoj nešto su više sklone prijaviti seksualno i/ili fizičko nasilje počinjeno od strane osobe s kojom su u vezi (22\%) nego ono počinjeno od strane osobe s kojom nisu (bile) u intimnoj vezi (20 \%). ${ }^{56} \mathrm{~S}$ druge strane, rezultati prvog sudjelovanja Hrvatske u ICVS studiji uputili su na velik domaći

52 Vidi iscrpno u: Bezić, R., Juvenile Delinquency in the Balkans: A Regional Comparative Analysis Based on the ISRD3-Study Findings, loc. cit. u bilj. 21.

53 Kao primjer raznovrsnosti izvora i raštrkanosti nalaza o viktimizaciji i tamnoj brojci kriminala možemo navesti čak i tzv. Eurobarometar, koji osim ispitivanja stavova ispitanika o širokom spektru sigurnosnih ugroza i državnih/europskih odgovora na njih u jednom dijelu ispituje i doživljenu viktimizaciju ispitanika kroz kibernetički kriminal, no ne i ostale vrste kriminala. Vidi: EU Open Data Portal, Special Eurobarometer 464b: Europeans' attitudes towards security, Directorate-General for Communication, s. l., 12. prosinca 2017.

54 Grupa autora, Istraživanja o “tamnoj brojci kriminaliteta”, Naša zakonitost, vol. 39, br. 5-6, 1985., prema: Ajduković, M., Razvoj i mogućnosti upotrebe samoiskaza kao izvora podataka o delinkventnom ponašanju, Zbornik Pravnog fakulteta u Zagrebu, vol. 38, br. 1, 1988., str. 68.

55 Bez obzira na odnos između počinitelja i žrtve, Hrvatska se nalazi u grupi država s najmanje detektiranog fizičkog i/ili seksualnog nasilja nad ženama u usporedbi s ostalim državama Europske unije. Vidi opširnije: European Union Agency for Fundamental Rights, op. cit. u bilj. 22, str. 28.

56 European Union Agency for Fundamental Rights, op. cit. u bilj. 22, str. 61. 
problem korupcije i prijevare potrošača. ${ }^{57}$ Uspoređujući na temelju ICVS-a opće stanje kriminala diljem Europe, nalazi iz 1992. godine upućuju na povoljno stanje u Hrvatskoj, ali se situacija pogoršava 1996. godine, kada bilježimo više stope kriminala od europskog prosjeka. ${ }^{58}$ Dok autori istraživanja uočeni porast djelomično objašnjavaju tzv. teleskopskim efektom ${ }^{59}$, porast kriminala svakako valja interpretirati i u kontekstu ratnog te poslijeratnog stanja u Hrvatskoj. ${ }^{60}$ Što se maloljetnika u Hrvatskoj tiče, prema BECAN-u nešto manje od polovice djece do srednjoškolske dobi doživi fizičko zlostavljanje, a djevojke (44\%) ga doživljavaju nešto učestalije od dječaka (37\%). ${ }^{61} \mathrm{~S}$ druge strane, prema rezultatima ISRD3 studije, najčešće je devijantno/delinkventno ponašanje mladih u Hrvatskoj konzumacija alkohola (75 \%) te skidanje ilegalnih sadržaja s interneta (56 \%), dok razmjerno mali udio vandalizira javne prostore grafitima (17\%) ili pak krade u trgovinama (11\%). ${ }^{62}$

Slično kao što ispitanici u Meksiku i Brazilu ne prijavljuju sitne krađe policiji jer ih zbog njihove učestalosti smatraju pretjerano trivijalnima, i građani

57 Šeparović i Turković u tom kontekstu navode kako se stupanj viktimizacije za imovinska kaznena djela ili nasilna kaznena djela kreće od 0.0 (krađa motora) do 2.9 (namjerno oštećenje automobila), stupanj viktimizacije za korupciju iznosi 16, a za prijevaru potrošača 34. Nadalje, stopa kriminala u petogodišnjem razdoblju od 1992. do 1996. godine najviša je za imovinski kriminal (57 \%), dok je za krađu vozila (10 \%) i nasilna kaznena djela dosta niža (12 \%). Ukupno gledajući, stopa viktimizacije za sva kaznena djela (nakon što se izuzmu prijevara potrošača i korupcija) iznosi $8 \%$, a dodatkom korupcije i prijevare potrošača stopa viktimizacije raste na 58 \%. Usporedi Šeparović, Z.; Turković, K., Žrtve zločina u Hrvatskoj: međunarodni projekt istraživanja žrtava zločina, Hrvatski ljetopis za kazneno pravo i praksu, vol. 4, br. 2, 1997., str. 545 - 561.

58 Cf. ibid., str. 562.

59 Vidi opširnije pojašnjenje u bilj. 92.

60 Naime, tzv. wartime drop kriminala u Hrvatskoj označava razdoblje relativno naglog pada registriranog kriminala za vrijeme i neposredno nakon Domovinskog rata te je posebno izraženo ako se analizira trend kretanja registriranog kriminala kroz duže razdoblje od 60 i više godina. Vidi opširnije: Getoš Kalac; Bezić, Criminology, crime and criminal justice in Croatia, loc. cit. u bilj. 4.

${ }_{61}$ Ajduković, M., et al., Epidemiološko istraživanje prevalencije i incidencije nasilja nad djecom u obitelji u Hrvatskoj, Ljetopis socijalnog rada, vol. 19, br. 3, 2012., str. 381.

62 Bezić, R., Juvenile Delinquency in the Balkans: A Regional Comparative Analysis of the ISRD3-Study Findings, u: Getoš Kalac, A.-M.; Albrecht, H.-J.; Kilchling, M. (ur.), Mapping the Criminological Landscape of the Balkans, A Survey on Criminology and Crime with an Expedition into the Criminal Landscape of the Balkans, Max-Planck-Gesellschaft zur Förderung der Wissenschaften e.V. in coop. with University of Zagreb - Faculty of Law and Duncker \& Humblot, Berlin, 2014., str. 440. 
Hrvatske ne prijavljuju primanje, odnosno davanje mita. ${ }^{63} \mathrm{U}$ studiji koja je provedena uz potporu Ureda za suzbijanje droge i kriminala Ujedinjenih naroda (engl. United Nations Office on Drugs and Crime; UNODC) $98 \%$ ispitanika koji nisu prijavili davanje mita nadležnim institucijama kao najčešće razloge neprijavljivanja navode "kako su i sami imali koristi od transakcije", "kako je mito zapravo znak zahvale" te kako "nikoga od nadležnih ne bi bilo briga". ${ }^{64}$ Budući da su policijski službenici s udjelom od čak $30 \%$ na trećem mjestu najčešćih primatelja mita, odmah nakon liječnika (56 \%) i medicinskih sestara (36 \%), može se pretpostaviti kako postoji određena suzdržanost pojedinaca u pogledu prijavljivanja koruptivnih kaznenih djela policiji jer potencijalni prijavitelji smatraju kako "svi policajci primaju mito". ${ }^{55}$ Ako ove rezultate povežemo s prije navedenim iz Ujedinjenog Kraljevstva i Walesa, prema kojima je povjerenje u policiju jedan od bitnih faktora za donošenje odluke o prijavljivanju kaznenog djela, takav nepovjerljiv stav hrvatskih građana prema policiji sigurno utječe i na razmjere tamne brojke kriminala u Hrvatskoj.

Novija istraživanja tamne brojke kriminala često su usmjerena na specifične skupine žrtava i/ili počinitelja. Tako rezultati istraživanja iz 2004. godine, provedenog metodom samoiskaza o maloljetničkom delinkventnom ponašanju na području Grada Zagreba i Zagrebačke županije, pokazuju kako je čak polovica ispitanika počinila kazneno djelo krađe (52 \%) dok je gotovo jedna četvrtina (22\%) nanijela lakšu tjelesnu ozljedu drugoj osobi, a nešto manje ih je izazvalo tučnjavu (17 \%) prije napunjene 18 . godine života. ${ }^{66}$ Gotovo polovica ispitanika (44 \%) navela je kako je konzumirala marihuanu i/ili hašiš, i to najčešće u društvu, što naravno upućuje na to kako bi udio takvih konzumenata mogao biti i mnogostruko veći. Ispitanici za navedena delikventna ponašanja nisu nikada bili prijavljeni ili kažnjeni, što upućuje na relativno visoku tamnu brojku. ${ }^{67}$

U Zagrebu je 2009. godine provedeno još jedno istraživanje, no ovaj put ono doživljene viktimizacije i usmjereno na nasilje nad starijim osobama u obitelji. ${ }^{68}$ Rezultati upućuju na pretežitu izloženost starijih osoba psihičkom nasilju

63 United Nations Office on Drugs and Crime, Corruption in Croatia: Bribery as experienced by the population, United Nations Office on Drugs and Crime, Beč, 2011., str. 29.

64 Ibid.

65 Cf. ibid., str. 23.

66 Bobetić, M. et al., Istraživanje tamne brojke delinkventnog i devijantnog ponašanja osoba do 18. godine života, Hrvatska revija za rehabilitacijska istraživanja, vol. 40, br. 2, 2004., str. 223.

67 Cf. ibid., str. 221.

68 Rusac, S., Nasilje nad starijim osobama u obitelji na području grada Zagreba, Ljetopis socijalnog rada, vol. 16, br. 3, 2009., str. $573-594$. 
(11 \%) od strane obitelji, dok fizičko nasilje doživljava vrlo mali udio ispitanika $(1 \%)^{69}$, a nešto više ga ipak doživljavaju oni koji su niže obrazovani ${ }^{70}$ i oni koji materijalno potpuno ovise o svojoj djeci. ${ }^{71}$ Iako nije pronađena značajna povezanost između spremnosti prijave fizičkog nasilja s izloženošću takvom nasilju, utvrđeno je kako su one osobe koje su manje sklone prijaviti psihičko nasilje ujedno i one osobe koje su mu i najviše izložene. ${ }^{72} \mathrm{~S}$ obzirom na to kako je istraživanje provedeno metodom intervjua "licem u lice", postavlja se pitanje je li u smislu pristupa ispitanicima zapravo realno očekivati kako su studijom mogli biti obuhvaćeni upravo i oni najteži slučajevi nasilja unutar obitelji nad starijim osobama jer je malo vjerojatno da bi potencijalni nasilnici dopustili sudjelovanje svojih starijih ukućana u takvu istraživanju.

U smislu posebno ranjivih skupina potencijalnih žrtava kažnjivih ponašanja svakako treba voditi računa i o tzv. rizičnim profesijama. 2014. godine provedeno je istraživanje među studentima Visoke policijske škole Ministarstva unutarnjih poslova Republike Hrvatske te je više od polovice ispitanika (55 \%) izjavilo kako je za vrijeme obavljanja službene dužnosti doživjelo neko od kaznenih djela napada na službenu osobu ili im je nanesena laka/teška tjelesna ozljeda. ${ }^{73}$ Zanimljivo je što čak i policijski službenici često ne prijavljuju vlastitu viktimizaciju ${ }^{74}$, no razloge za neprijavljivanje prije bi trebalo ispitati u kontekstu policijske supkulture, negoli vezano uz (ne)povjerenje u rad kolega na poslovima progona i sl.

Iako je u biti riječ o europskom istraživanju javnog mnijenja, u kontekstu domaće rasprave o tamnoj brojci kriminala na kraju ovog drugog dijela rada svakako je zanimljivo spomenuti percepciju građana Hrvatske u odnosu na stanje kriminala, odnosno njihov doživljaj kriminala kao manje ili pak više istaknutog problema. Dok u prosjeku građani država članica Europske unije (EU28) problem kriminala vide tek na 10 . mjestu po pitanju važnosti izazova s kojima se susreće njihova država (11 \%), Hrvati problem kriminala stavljaju čak na 4. mjesto po važnosti ( $24 \%$ ) i usko uz izazove porasta troškova (života) i inflacije $(25 \%)$ te ekonomske situacije (26 \%), a na prvo mjesto stavljaju nezaposlenost

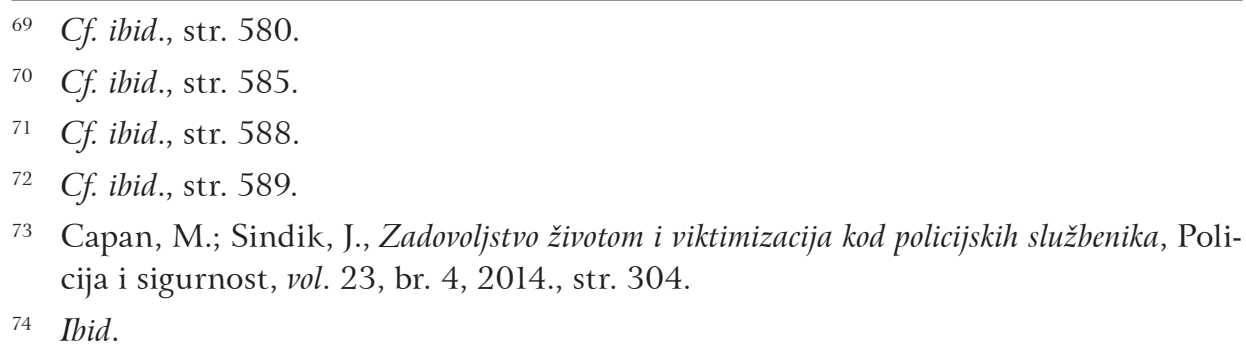


(33\%), kao što je to slučaj i u zemljama EU28 (21 \%). ${ }^{75}$ Sličnu percepciju važnosti izazova povezanih s kriminalom Hrvati u velikoj mjeri projiciraju na EU, pa kada rangiraju važnost izazova s kojima se ne susreće njihova država već EU u cjelini, onda problem kriminala stavljaju na visoko 3. mjesto (16\%), a terorizam na 2. mjesto (33\%). Navedeno je tim više paradoksalno što Hrvatska pripada u rang onih država koje imaju razmjerno niske stope registriranog kriminala, posebice $u$ odnosu na tzv. ulični kriminal i nasilne delikte. ${ }^{76}$ Je li po pitanju ovog paradoksa riječ tek o dobro poznatom fenomenu razilaženja laičke percepcije o kriminalu od registriranog kriminala ili o mogućoj velikoj tamnoj brojci kriminala u Hrvatskoj, nije moguće utvrditi bez nalaza nacionalnih viktimizacijskih studija. No, u svakom slučaju vrijedna je spoznaja što je kriminal sasvim očito tema kojoj građani u Hrvatskoj (za razliku od onih u EU28) pridaju veliku važnost, slijedom čega se može očekivati kako bi otpočinjanje znanstvenog i stručnog diskursa o tamnoj brojci kriminala te presudnom značenju nacionalnih viktimizacijskih studija za njezino rasvjetljavanje moglo biti od istaknute važnosti za sve aktere uključene u ili vezane uz kazneno pravosuđe.

\section{TAMNA STRANA TAMNE BROJKE KRIMINALA: IZAZOVI ISTRAŽIVANJA NEPOZNANICA}

U nastavku je analiziran izbor najznačajnijih konceptualnih i metodoloških izazova konstrukcije i istraživanja tamne brojke kriminala. Kako je kod ove tamne strane tamne brojke riječ o dobro poznatim kriminološkim izazovima, pojašnjenja su svedena na najmanju moguću mjeru, dok se više prostora daje raspravi najspornijih izazova koji su podjednako važni i za kaznen(opravn)u znanost i praksu, ali i za laičko razumijevanje geneze i konzumacije podataka o (ne)registriranom kriminalu.

\subsection{Konceptualni izazovi konstrukcije (tamne brojke) kriminala}

Povijest statistika o kriminalu zapravo predstavlja svojevrsnu potragu za "mjernom jedinicom kriminala" u određenoj populaciji. ${ }^{77} \mathrm{O}$ izazovu tamne

75 Vidi: EU Open Data Portal, Special Eurobarometer 464b: Europeans' attitudes towards security, loc. cit. u bilj. 53.

76 Vidi nalaze 1. do 5. kruga prikupljanja podataka za European Sourcebook of Crime and Criminal Justice Statistics u kojima podaci za Hrvatsku redovito upućuju na razmjeno niske stope kriminala u europskoj usporedbi: https://wp.unil.ch/europeansourcebook/printed-editions-2/ (1. rujna 2020.).

77 Biderman, A. D.; Reiss, A. J., On Exploring the "Dark Figure" of Crime, The ANNALS of the American Academy of Political and Social Science, vol. 374, br. 1, 1967., str. 1. 
brojke kriminala prvi se put raspravlja još davne 1836. godine. ${ }^{78}$ Usporedno s razvojem statistika o kriminalu raste i znanstvena te praktična opsjednutost tamnom brojkom kriminala, odnosno onim događajima koji se prema nekim kriterijima nazivaju kriminalom, iako nisu kao takvi registrirani od strane tijela kaznenog progona. ${ }^{79}$ Razilaze se "realisti", koji ističu vrline sveobuhvatnosti kojom podaci reflektiraju "stvarni kriminal" s jedne strane, i "institucionalisti”, koji naglašavaju kako kriminal može imati validno značenje isključivo u kontekstu organizirane i legitimne društvene reakcije na njega. ${ }^{80} \mathrm{U}$ konačnici ni jedna od ove dvije perspektive nije točna. Nije, doduše, ni jedna netočna, no valja se složiti s Biderman i Reiss kada već 1967. godine ističu promašenost obiju perspektiva jer svaki set statistika o kriminalu (bile to službene statistike registriranog kriminala, ili pak statistike proizašle iz viktimizacijskih istraživanja) nužno prolazi kroz određeni filter evaluativnog i institucionalnog procesuiranja onoga o čemu osobe/ispitanici iskazuju. ${ }^{81}$

Kao što ne postoji konsenzus o tome kojim bi se izvorima ili vrstama statistika o kriminalu trebala dati prednost, tako nije moguće ni točno utvrditi ili pak provjeriti opseg ili sadržaj tamne brojke kriminala. ${ }^{82}$ Svaki izvor i svaka vrsta

78 Bulwer, H. L., France, Social, Literary, Political, vol. 1, Richard Bentley, London, 1836., prema: cf. ibid., str. 2.

79 Biderman; Reiss, On Exploring the "Dark Figure" of Crime, loc. cit. u bilj. 77.

80 Ibid.

81 Ibid.

82 Recentna istraživanja tamne brojke kriminala u sferi najpogibeljnijih nasilnih delikata pokazuju kako čak i u slučaju ubojstava, za koja se uobičajeno polazi od pretpostavke kako im je tamna brojka iznimno mala, zapravo gotovo zanemariva, postoji osobito visok udio onih nasilnih smrti koje ostaju neotkrivene, odnosno koje inicijalno bivaju pogrešno klasificirane kao prirodne smrti, iako je de facto riječ o sumnjivim smrtima kod kojih bi bilo nužno izvršiti obdukciju radi ispitivanja i utvrđivanja točnog uzroka smrti. No, kako se te smrti inicijalno pogrešno klasificiraju kao prirodne, nema ni obdukcije, pa tako svi ti slučajevi ostaju neotkriveni. U Njemačkoj se procjenjuje kako svaka druga nasilna smrt ostaje neotkrivena. Još je u 90-im godinama 20. stoljeća utvrđeno kako godišnje više od 10.000 neprirodnih smrti u Njemačkoj ostaje neotkriveno, pri čemu se kod najmanje 1200 slučajeva procjenjuje kako je zapravo riječ o ubojstvima. Novija studija iz 2017. godine, kojom je analizirana dokumentacija 10.000 smrtnih slučajeva u razdoblju od 2012. do 2015. godine, uvelike potvrđuje navedene procjene velike tamne brojke te je utvrđena najmanje jedna ozbiljna pogreška liječnika mrtvozornika u čak $27 \%$ analiziranih slučajeva. Vidi: Universität Rostock, Die meisten Todesbescheinigungen weisen Fehler auf: Studie der Uni Rostock bringt erschreckende Fakten ans Tageslicht, 1. rujna 2017.; Esanum, Studie zeigt große Mängel bei Leichenschau: Mit dem Messer im Rücken ins Krematorium?, 4. prosinca 2017. Pretpostavlja se kako je uzrok ovako velike tamne brojke povezan 
podataka o kriminalu pati od svojih specifičnih konceptualnih i metodoloških nedostataka te vlastite tamne brojke, tako da u konačnici ne preostaje ništa drugo negoli kriminološke spoznaje crpiti iz kombinirane analize nekoliko različitih izvora i vrsta statistika o kriminalu ${ }^{83}$ te tako dobivene spoznaje interpretirati kao ono što jesu - manjkava konstrukcija specifične društvene predodžbe o kriminalu, a ne kao ono što bismo željeli da budu - objektivna slika o stvarnom kriminalu. Podaci sadržani u statistikama o kriminalu nisu nekakav objektivno opipljiv univerzum "kriminalnih radnji", već upravo oni događaji koje kao kriminalne definira, zabilježi i procesuira neki institucionalni mehanizam ${ }^{84}$, bila to policija, državno odvjetništvo, sudovi ili pak znanstvenici, praktičari iz sfere zaštite žrtava u nevladinu sektoru ili istraživački novinari.

Netom navedenoj problematici, naravno, treba dodati još i pitanje interesa s kojim i svrhe za koju se konstruiraju, prikupljaju i koriste pojedine vrste statistika o kriminalu. Jasno je da će znanstvenici podatke prikupljati i analizirati s isključivim ciljem stvaranja novih spoznaja o kriminalu te utvrđivanja što realnije slike kriminala unutar promatrane populacije. S praktičarima je situacija pak malo drukčija. Ključni akteri kaznenog pravosuđa ${ }^{85}$ podatke o kriminalu ponajprije prikupljaju i analiziraju u sklopu redovitog praćenja i izvještavanja o svojem radu i njegovoj efikasnosti te radi potkrjepljivanja kriminalnopolitičkih odluka. Moglo bi se stoga reći kako je u prvom redu riječ o svojevrsnom "administrativnom vođenju knjiga i računovodstvu kaznenog pravosuđa”, dok prikupljeni podaci tek $u$ drugom redu služe i za procjenu stanja te kretanja kriminala u promatranoj populaciji u određenom prostoru i vremenu, opet ne s temeljnim ciljem stjecanja empirijskih spoznaja o kriminalu, već radi optimiziranja otkrivačke djelatnosti, progona i prevencije kriminala te maksimalno efikasne alokacije ograničenih ljudskih, tehničkih i materijalnih resursa. U tom

s udaljenošću od mjesta pronalaska leša ili nastupanja smrti do forenzičkih instituta, nedostatkom forenzičkog iskustva i specijaliziranosti liječnika mrtvozornika te lošom plaćenošću za njihov izlazak na teren radi utvrđivanja smrti. Imajući sve navedeno $\mathrm{u}$ vidu te s obzirom na okolnost kako u Hrvatskoj poslove mrtvozornika u praksi podjednako često obavljaju i liječnici, ali umjesto njih i medicinski tehničari odnosno medicinske sestre, osnovano se može pretpostaviti kako je tamna brojka ubojstava u nas u najmanju ruku podjednako dramatična kao i u Njemačkoj, ako ne i veća.

83 Npr. policijske statistike o prijavljenom kriminalu, počiniteljima i žrtvama, statistike o samodoživljenoj viktimizaciji, sudske statistike o pravomoćno osuđenim osobama, samoiskazi o delinkventnom ponašanju, statistike zatvorskog sustava i sl. Biderman; Reiss, On Exploring the "Dark Figure" of Crime, loc. cit. u bilj. 77.

85 Npr. policija, državno odvjetništvo i sudovi, ali i zatvorski sustavi, probacijske službe te sva njihova matična ministarstva, kao i statistički zavodi i dr. 
su smislu statistike o (ne)registriranom kriminalu, ovisno o njihovoj praktičnoj ili pak znanstvenoj svrsi, uvelike predodređene u pogledu svoje specifične spoznajne kvalitete.

Prebacimo li sada raspravu o tamnoj strani tamne brojke nakratko s upravo prikazane razine kaznen(opravn)e znanosti i prakse na metaznanstvenu razinu, onda uočavamo kako se konceptualni izazovi (konstrukcije) tamne brojke mijenjaju ovisno o tome zauzimamo li pozitivističku ili pak konstruktivističku perspektivu. Naime, društvene teme poput kriminala i kazne nisu ontološke veličine, već su kao takve određene od strane društva i pod utjecajem specifičnih okolnosti-njihovo određivanje zahtijeva duplu konstrukciju, koja s jedne strane rekonstruira već postojeće društvene konstrukcije, dok pri tome s druge strane unosi još i vlastite nove prijedloge tumačenja tih istih konstrukcija. ${ }^{86}$ Drugim riječima, ono što je kriminalno prethodno je definirano kao kriminalno od strane društva (npr. kaznenim zakonima), a zatim kao kriminalno prepoznato, redefinirano, prihvaćeno ili pak odbačeno od strane promatrača (npr. državni odvjetnik). Jasno je kako se ovisno o prvoj i drugoj konstrukciji "kriminala" (kazneni zakon ili mediji) te različitim vrstama promatrača, odnosno "konstruktora" (policajci, državni odvjetnici, suci ili pak građani laici) mijenja i sama predodžba o "kriminalu". Riječ je o konceptualnom izazovu koji nije moguće svladati, pri čemu se središnja zabluda sastoji od pogrešnog poimanja kriminalnih događaja kao nekakvih objektivno odredivih i realno postojećih sastavnih dijelova zbilje. ${ }^{87}$ Kriminal je zapravo o situaciji ovisna interpretacija određene radnje, a ne sama radnja koja bi u svojem biću imala kakvo "kriminalno" značenje. ${ }^{88}$

Konstrukcija kriminala s konceptualnog aspekta postaje posebno problematična kada je riječ o viktimizacijskim studijama ili pak istraživanjima vlastitog delinkventnog ponašanja ispitanika, za čije se nalaze nerijetko tvrdi kako rasvjetljavaju tamnu brojku službeno registriranog kriminala. Građani ispitanici kod takvih istraživanja redovito interpretiraju "kriminalno svojstvo" određenih radnji upravo onako kako vjeruju da bi ih interpretiralo kazneno pravosuđe u slučaju kada bi za njih doznalo - takva dupla interpretacija građana, koja hipotetski anticipira nepostojeću interpretaciju kaznenog pravosuđa, izvire iz laičke, medijima obilježene i populizmu sklone perspektive. ${ }^{89}$ Slijedom navede-

86 Kunz, K.-L., Unentdeckte Straftaten aus konstruktivistischer Sicht - ein Beitrag zum Verständnis des Dunkelfeldes, Monatsschrift für Kriminologie und Strafrechtsreform, vol. 103, br. 2, 2020., str. 245.

87 Cf. ibid., str. 246.

88 Ibid.

89

Cf. ibid., str. 247. 
noga kongruentnost takvim istraživanjima utvrđene tamne brojke kriminala s registriranim kriminalom i duplom tamnom brojkom kriminala čini se krajnje dvojbenom ${ }^{90}$, dok se korist od takvih istraživanja tamne brojke u biti može svesti na društveni barometar raspoloženja i argumentacijsko pomagalo praksi kreiranja kriminalne politike..$^{91}$

\subsection{Metodološki i praktični izazovi istraživanja tamne brojke kriminala}

Pri korištenju metode samodoživljene viktimizacije, osim što nalazi istraživanja variraju ovisno o faktorima kao što su primjerice način ispitivanja (licem u lice intervjuom, pisanim ili on-line obrascem i sl.), dobiveni rezultati ne moraju nužno biti točni jer ispitanici ponekad nisu ni svjesni vlastite viktimizacije, što zbog same vrste kažnjivog ponašanja (npr. prijevara), što zbog vlastitog statusa i/ili ranjivosti (npr. nasilje nad djecom ili starijim osobama). Osim toga, nije moguće ni potpuno se pouzdati u točnost iskaza ispitanika s obzirom na razdoblje ${ }^{92}$ i/ili (višestruku) reviktimizaciju te je stoga potrebno prilagoditi redoslijed pitanja u upitnicima kako bi se ovaj efekt što više držao pod kontrolom. ${ }^{93}$ Slično tome, viktimizacijske se studije ponajviše oslanjaju na sjećanje sudionika, koje nije savršeno, te je moguće da će sudionici one delikte

90 Vidi iscrpno: Kunz, K.-L., Die wissenschaftliche Zugänglichkeit von Kriminalität, Ein Beitrag zur Erkenntnistheorie der Sozialwissenschaften, VS Verlag für Sozialwissenschaften, Wiesbaden, 2008.

91 Kunz, op. cit. u bilj. 86, str. 9.

92 Većina viktimizacijskih studija ispitanike ispituje o (mogućoj) doživljenoj viktimizaciju u posljednjih godinu dana, ili nekom drugom određenom razdoblju. Ispitanici u jednakoj mjeri mogu za određeni događaj smatrati kako se dogodio prije tog razdoblja te ga, posljedično, ne prijaviti pri ispitivanju, ili ga se pogrešno prisjetiti kao puno recentnijeg nego što uistinu jest (tzv. teleskopski efekt) te se na taj način povećava/smanjuje tamna brojka. Vidi opširnije: Maxfield, M. G.; Babbie, E. R., Research methods for criminal justice and criminology, 7th Edition, Cengage Learning, Boston, 2014., str. 150.

93 Utvrđeno je kako sudionici manje griješe pri smještanju kažnjivog ponašanja u točno razdoblje kada ih se traži da odaberu godinu doživljene viktimizacije. Usporedi Linde, A.; Aebi, M. F., Les enquestes de victimització com a instrument de mesura de la delinqüència $i$ de la inseguretat, u: Murrià-Sangenis, M.; Sobrino Garcés, C.; González-Murciano, C. (ur.), 30 Anis de l'Enquesta de Victimizació de l'Àrea Metropolitana de Barcelona: Vigència $i$ ús de les enquestes de seguretat a les metròpolis, Institut d'Estudis Regionals i Metropolitans de Barcelona, Barcelona, 2020., str. 85. 
koje nisu doživjeli toliko traumatičnima i lakše zaboraviti (navesti). ${ }^{94}$ Dodatni izazov pred viktimizacijske studije stavlja ispitivanje osoba koje kazneno djelo dožive u državi čiji nisu građani ili čiji jezik ne poznaju (npr. turisti). Istraživanja pokazuju kako takve žrtve oklijevaju u prijavi kažnjivih ponašanja, što ne samo povećava tamnu brojku, već ih i čini lakšim metama jer počinitelji u slučaju takvih žrtava procjenjuju da je vjerojatnost njihova otkrivanja smanjena. ${ }^{95} \mathrm{~K}$ tome je $\mathrm{u}$ kontekstu viktimizacijskih istraživanja gotovo nemoguće takvu populaciju žrtava reprezentativno uključiti u uzorak ispitanika. ${ }^{96}$

Posebno su problematične kategorije ispitanika kojima istraživači teško uspijevaju pristupiti. To se u prvom redu odnosi na sve osobe koje se nalaze $u$ nekoj vrsti institucionalne skrbi (npr. zatvorenici, bolesnici, migranti i sl.) ili pak osobe starije životne dobi koje trpe zlostavljanje od strane svojih ukućana ili pak unutar ustanova od strane stručnog osoblja. ${ }^{97}$ Osobe starije životne dobi u tom smislu predstavljaju iznimno važan metodološki aspekt reprezentativnosti uzorka, a imajući u vidu signifikantnost rastućeg udjela starijeg stanovništva u Hrvatskoj. ${ }^{98}$ Slična je i problematika istraživanja pojedinih vrsta delikata koji su fenomenološki gledano osjetljive naravi i/ili razmjerno rijetki. ${ }^{99} \mathrm{U}$ svrhu procjene tamne brojke kod seksualnog iskorištavanja i sličnih kaznenih djela kod kojih je

94 Sudman, S.; Bradburn, N. M., Effects of time and memory factors on response in surveys, Journal of the American Statistical Association, vol. 68, br. 344, 1973., str. 809.

95 Victim Support Europe, Cross-border Victimisation, Challenges and solutions with respect to the provision of support to victims of crime in a cross-border situation, s. l. a. n., str. 25.

$96 \mathrm{Za}$ detaljan pregled (povijesnog razvoja) međunarodnih viktimizacijskih studija vidi: Linde; Aebi, Les enquestes de victimització com a instrument de mesura de la delinqüència i de la inseguretat, loc. cit. u bilj. 93.

97 Vela Vrabec, N., Nasilje nad starijim osobama, ružna strana društva, Narodni zdravstveni list, br. 626-627, 2012., str. 18.

98 Budući da se nakon ulaska u Europsku uniju pa do sredine 2013. godine iz Hrvatske iselilo u prosjeku 200.000 (pretežito mladih) ljudi, a i da Hrvatska nije nužno omiljena destinacija za imigraciju, stanovništvo u Hrvatskoj (p)ostalo je puno starije nego prije. Može se očekivati kako će ovakvo stanje utjecati na kriminal i na prilagodbu mehanizama za nošenje s kriminalom te kako će se s godinama moći primijetiti promjena u učestalosti, strukturi i fenomenologiji kriminala u Hrvatskoj. Vidi opširnije: Podgornik, B., Podaci OECD-a: Ubrzava se iseljavanje iz Lijepe Naše - u dvije godine iz Hrvatske odselilo 138 tisuća ljudi, Novi list, 13. kolovoza 2017.

99 Kao primjer možemo navesti trgovanje ljudima. Istraživanja koja su utvrdila vrlo mali broj zabilježenih slučajeva trgovanja ljudima u svrhu seksualnog iskorištavanja upućuju na potrebu za alternativnom metodom istraživanja tamne brojke kriminala kod suvremenog ropstva. Usporedi van Dijk, J. J. M., Illuminating the Dark Figure of Crime: Victimisation Surveys and Beyond, Criminology in Europe, vol. 15, br. 3, 2016., str. 8. 
pristup žrtvama otežan, metoda procjene više sustava koji bilježe žrtve kaznenih djela (engl. Multiple Systems Estimation; MSE) pokazala se sveobuhvatnijom od uobičajenih viktimizacijskih istraživanja. ${ }^{100}$

Iako se metodom samoiskaza o delinkventnom ponašanju mogu istražiti oni delikti koje je otežano proučavati metodom samodoživljene viktimizacije, postavlja se, naravno, pitanje koliko je pouzdano vjerovati u iskrenost sudionika, posebice ako oni sumnjaju u anonimnost prikupljanja podataka i/ili ih je strah kako bi njihovo kažnjivo ponašanje moglo biti prijavljeno policiji. ${ }^{101}$ Može se pretpostaviti stoga kako će rezultati prikupljeni ovom metodom bolje detektirati lakša i srednje teška kaznena djela, dok će teža i najteža kaznena djela, odnosno njihova tamna brojka, ostati nerasvijetljena.

Kategorija tzv. zločina bez žrtve pred viktimizacijske studije postavlja dodatne izazove. U tu skupinu primjerice pripadaju transakcijske kriminalne radnje na ilegalnom tržištu roba i usluga (npr. droge ${ }^{102}$ ), koruptivni delikti ${ }^{103}$, pranje novca, utaja poreza, gospodarski kriminal ili delikti na štetu okoliša. ${ }^{104}$ Tamna brojka kod ovih skupina delikata pretpostavljeno je vrlo visoka jer najčešće ne postoji neposredna žrtva koja bi prijavila kazneno djelo, niti navela da ga je doživjela u viktimizacijskoj studiji, dok potencijalni svjedoci uočene događaje često ne smatraju dovoljno teškim da bi se uključila policija ${ }^{105}$ ili se ne osjećaju osobno "pozvanima" prijaviti takve događaje.

100 Originalno preuzeta iz bioloških procjena staništa životinja na određenom području, metoda se temelji na usporedbi nekoliko službenih baza podataka žrtava, kao što bi primjerice bila baza podataka MUP-a, DZS-a i drugih (ne)državnih institucija. Usporedbom količine (ne)preklapanja popisa žrtava matematičkom formulom procjenjuje se koliko žrtava nije obuhvaćeno ni s jednom od baza, odnosno tamna brojka određenog kaznenog djela. Teza je kako je tamna brojka veća što je preklapanje među različitim bazama manje. Vidi: Silverman, B., Modern Slavery: an Application of Multiple Systems Estimation, Home Office, London, 2014., str. 5.

101 Piquero, A. R.; Farrington, D. P.; Blumstein, A., Key Issues in Criminal Career Research, Cambridge University Press, Cambridge, 2007., str. 166.

102 Maxfield; Babbie, op. cit. u bilj. 92, str. 149.

103 Vidi primjerice: Derenčinović, D., Prilog raspravi o rasvjetljavanju velike "tamne brojke" kod korupcijskih kaznenih djela, u: Mlinarević M. (ur.), Korupcija - pojavni oblici i mjere za suzbijanje, Inženjerski biro, Zagreb, 2008., str. 172 - 185.

${ }^{104} \mathrm{O}$ istraživanjima ilegalnih tržišta i specifičnim metodološkim izazovima vidi: Wehinger, F., Illegale Märkte: Stand der sozialwissenschaftlichen Forschung, Max-Planck-Institut für Gesellschaftsforschung, Cologne, 2011.

105 Korsell, L. E., Big stick, little stick: Strategies for controlling and combating environmental crime, Journal of Scandinavian Studies in Criminology and Crime Prevention, vol. 2, br. 2, 2001., str. 131. 
Prethodno navedenim metodološkim izazovima specifičnim za područje istraživanja kriminala svakako treba dodati još i sve one metodološke izazove koji se općenito javljaju pri osmišljavanju i provođenju empirijskih istraživanja u društvenim znanostima te analizi i interpretaciji dobivenih podataka. Ti izazovi ponajprije uključuju uzorkovanje (npr. probabilističko, odnosno neprobabilističko), prostorni i vremenski opseg (npr. kros-sekcijske ili longitudinalne studije, pri čemu posljednje mogu biti prospektivne i/ili retrospektivne), jedinicu mjerenja (npr. žrtva i/ili počinitelj i/ili događaj), ciljanu populaciju, konceptualizaciju ključnih fenomena te određivanje odgovarajućih varijabli, deskriptivne i/ili kauzalne inferencije, validnost i pouzdanost ${ }^{106}$, ali i tzv. missing data problem. ${ }^{107}$

Jasno je kako splet specifično kriminoloških te općih metodoloških izazova koji se nužno javljaju pri pokušajima rasvjetljavanja tamne brojke kriminala, zajedno sa (zasada) nepremostivim konceptualnim izazovima konstrukcije "kriminala" i njegove tamne brojke, u biti sva postojeća "mjerenja" kriminala i njegove tamne brojke čine u većoj ili manjoj mjeri upitno egzaktnima i u konačnici uvelike neprovjerljivima. To se podjednako odnosi i na spoznaje dobivene iz podataka o službeno registriranom kriminalu, i na spoznaje proizašle iz viktimizacijskih studija, istraživanja vlastitog delinkventnog ponašanja samoiskazom, ali i na druge vrste empirijskih kriminoloških istraživanja općenito. Slijedom toga su i trenutačne kriminološke spoznaje o (ne)registriranom kriminalu i njegovoj tamnoj brojci u većoj ili manjoj mjeri nužno spekulativne, pa ih kao takve valja i konzumirati s (većom ili manjom) dozom opreza. Iako je nesporno kako netom analizirana i ukratko skicirana situacija upućuje na spoznajni deficit, i u kazneno(pravno)j znanosti i u praksi, postavlja se pitanje je li to isključivo problem s jasnim negativnim predznakom, ili je možebitno istovremeno riječ i o nekoj vrsti blagoslova neznanja što zapravo nemamo točnu predodžbu o stvarnim razmjerima kriminala. Na to pitanje o mogućoj svijetloj strani tamne brojke kriminala odgovorit ćemo u nastavku.

106 Vidi opširnije: Brame, R., Quantitative criminology, u: Miller, J. M. (ur.), 21st Century Criminology: a Reference Handbook, Sage, Thousand Oaks, 2009., str. 437 - 446.

107 O izazovima koji se javljaju vezano uz tzv. missing data kod istraživanja ubojstava te mogućim rješenjima vidi primjerice: Riedel, M.; Regoeczi, W. C., Missing Data in Homicide Research, Homicide Studies, vol. 8, br. 3, 2004., str. 163 - 192. 


\section{SVIJETLA STRANA TAMNE BROJKE KRIMINALA: PREVENTIVNI UČINAK NEZNANJA}

Iako prvi put iznesena davne 1968. godine te u njemačkom govornom području odavno uvrštena među ključne spoznaje kaznen(opravn)ih znanosti, Popitzova teza o funkciji tamne brojke u službi stabilizacije normi (njem. Normstabilisierungsfunktion des Dunkelfelds) ${ }^{108}$, u domaćim znanstvenim i stručnim raspravama nije adekvatno percipirana. Kako navedena teza o preventivnom učinku neznanja (njem. Präventivwirkung des Nichtwissens) u sebi ujedno sadržava i odgovor na netom postavljeno pitanje o mogućoj svijetloj strani tamne brojke kriminala, ukratko ćemo iznijeti njezine glavne odrednice te analizirati njihovu empirijsku održivost.

Popitzova teza u biti dovodi u pitanje općeprihvaćeno stajalište prema kojemu je poželjno u što većoj mjeri razotkriti i kazniti sva kršenja normi. Takvo se stajalište temelji na uvjerenju kako sve kriminalne radnje treba sankcionirati te da kazna zapravo djeluje poput određene nelagode. ${ }^{109}$ Prema Popitzu tamna je brojka kriminala zapravo neznanje koje je nužan uvjet funkcioniranja društva. Kada bismo znali za sva bezbrojna kršenja normi, do kojih dolazi svakodnevno i u svim slojevima društva, tada norme više ne bi imale važenje norme, tj. u biti više ni ne bi bile norme. Dok određena doza (pre)poznatih kršenja norme potvrđuje njezino važenje, sveobuhvatno bi otkrivanje svih devijantnih ponašanja uništilo iluziju o važenju norme, a time i temelj svega društvenoga. ${ }^{110}$

Kada se (prijestup) norme više ne sankcionira ili prerijetko sankcionira, onda joj ispadaju zubi - ako mora stalno gristi, zubi će joj otupiti. Ali ne gubi samo sankcija svoju težinu kada susjed s desne is lijeve biva sankcioniran. Time ujedno postaje očito - i to na zamislivo jasan način - kako se i susjed ne pridržava norme. No, ova demonstracija razmjera nevaženja norme će, kao i gubitak snage sankcije, utjecati na spremnost za konformnim ponašanjem. Ako ih previše završi na stupu srama, ne gubi samo stup srama svoje užase, već i kršenje norme svoj karakter iznimke te time i karakter djela, kojim je nešto "slomljeno", polomljeno. ${ }^{111}$

108 Popitz, H., Über die Präventivwirkung des Nichtwissens (1968), Mit einer Einführung von Fritz Sack und Hubert Treiber, Berliner Wissenschafts-Verlag, Berlin, 2003.

109 Popitz, H., Über die Präventivwirkung des Nichtwissens, Dunkelziffer, Norm und Strafe, u: Klimke, D.; Legnaro, A. (ur.), Kriminologische Grundlagentexte, Springer VS, Wiesbaden, 2016., str. 33.

110 Cf. ibid., str. 34.

111 Prijevod citata iz: Popitz, op. cit. u bilj. 108, str. 19 - 20. Izvorno: Wenn die Norm nicht mehr oder zu selten sanktioniert wird, verliert sie ihre Zähne, - muß sie dauernd zubeißen, werden ihre Zähne stumpf. [...] Aber nicht nur die Sanktion verliert ihr Gewicht, 
Suvišno je u ovom kontekstu posebno argumentirati kako osim toga ni jedan kaznenopravni sustav ne bi podnio gonjenje i sankcioniranje sveobuhvatno otkrivenih kažnjivih ponašanja. Stoga tamna brojka kriminala svakako ima i svoju svijetlu stranu, čija pozitivna funkcija (zbog dramatičnosti razmjera njezina po društvo ključnog djelovanja) preteže nad negativnim aspektima njezine tamne strane:

Društvena djelotvornost kazne moguća je samo i upravo zato što većina ne "dobije što zaslužuje". I preventivno djelovanje kazne moguće je samo ako se očuva generalna prevencija tamne brojke kriminala. Sjaj i bijeda kazne temelje se na "čudesnom, lijepom proviđenju prirode", kojoj možemo zahvaliti na tome "što oni nisu upućeni" - ili pak vrlo slabo upućeni. ${ }^{112}$

$\mathrm{Na}$ kraju se, naravno, postavlja pitanje empirijske provjere i održivosti Popitzove teze. Osim brojnih kriminoloških i socioloških istraživanja koja se bave pojedinim aspektima konformnog pa i devijantnog ponašanja, ${ }^{113}$ a koja mahom potvrđuju periferne teze koje omeđuju Popitzovu ideju o preventivnom učinku neznanja, posebno su zanimljivi nalazi jednog novijeg eksperimentalnog istraživanja provedenog s ciljem provjere upravo Popitzove teze. Diekmann, Przepiorka i Rauhut jednostavnim su eksperimentom ispitali (u)koliko rasvjetljavanje tamne brojke doista dovodi do porasta kršenja normi i zbilja su ustanovili kako rasvjetljavanje tamne brojke, odnosno stvaranje "transparentnosti ponašanja”, dovodi do većih razmjera kršenja normi: informiranost ispitanika o stvarnom (devijantnom) ponašanju povećava pojavnost kršenja normi. ${ }^{114}$ Pojednostavljeno, kada znamo kako i drugi oko nas krše norme, skloniji smo i sami

wenn der Nachbar zur Rechten und zur Linken bestraft wird. Es wird damit auch offenbar - und zwar in denkbar eindeutiger Weise -, daß auch der Nachbar die Norm nicht einhält.

Diese Demonstration des Ausmaßes der Nichtgeltung der Norm wird sich aber ebenso wie der Gewichtsverlust der Sanktion auf die Konformitätsbereitschaft auswirken. Werden allzu viele an den Pranger gestellt, verliert nicht nur der Pranger seine Schrecken, sondern auch der Normbruch seinen Ausnahmecharakter und damit den Charakter einer Tat, in der etwas 'gebrochen', zerbrochen wird.

112 Smisao prijevoda citata iz: Popitz, op. cit. u bilj. 108, str. 23. Izvorno: Die Strafe kann ihre soziale Wirksamkeit nur bewahren, solange die Mehrheit nicht "bekommt was sie verdient”. Auch die Präventivwirkung der Strafe bleibt nur bestehen, solange die Generalprävention der Dunkelziffer erhalten bleibt. Glanz und Elend der Strafe beruhen auf "der wundervollen, der schönen Fürsorge der Natur", der wir es verdanken, "daß sie nicht Bescheid wissen" - oder doch sehr wenig.

113 Vidi primjerice eksperimente Solomona Ascha, Stanleya Milgrama ili Philipa Zimbarda.

114 Diekmann, A.; Przepiorka, W.; Rauhut, H., Die Präventivwirkung des Nichtwissens im Experiment, Zeitschrift für Soziologie, vol. 40, br. 1, 2011., str. 79. 
kršenju norme. Važnost takvog empirijskog nalaza te Popitzove teze valjalo bi prepoznati i u kaznen(opravn)oj znanosti i praksi te na primjeren način unijeti u javnu te medijsku raspravu o kriminalu, njegovu otkrivanju i sankcioniranju. Ne s ciljem relativiziranja važnosti kaznenopravnog progona ili opravdavanja slabe otkrivačke djelatnosti i znanosti i prakse, već s ciljem relaksacije emotivno i senzacionalistički nabijenih rasprava o kriminalu, koje sve češće poprimaju oblike javnog pozivanja na linč ${ }^{15}$ i glorifikacije vigilantizma. ${ }^{116}$ Izvjesno je kako bi politika suzbijanja kriminala, koja također sve češće na emotivno i senzacionalistički nabijene rasprave o kriminalu odgovara penalnim populizmom, odnosno brzopletim i upitno smislenim normativnim zahvatima ${ }^{117}$, a ne usmjeravanjem, smirivanjem ili prosvjetljivanjem javnog diskursa, mogla kreirati više (novih) problema od onih koje nastoji riješiti.

115 Vidi npr. javni diskurs recentnih slučajeva seksualnog nasilja u Zadru (Mladiće osumnjičene za grupno silovanje maloljetne Zadranke dovode u zatvor: pogledajte snimku privođenja, Net.hr, 17. listopada 2019.) ili pak izvještavanja o slučaju nasilja u Kaštelama (T. A., Nasilnici iz Kaštela: Policija objavila detalje odvratnog zlostavljanja koje je užasnulo Hrvatsku, Dnevnik, 31. kolovoza 2020.).

116 Tako primjerice nedavna javna i medijska rasprava o slučaju višestrukog ubojstva u Splitu (Hina, Stručnjaci o podršci trostrukom ubojici: "Riječ je o fenomenu koji je u dva dana poprimio tolike razmjere da bi mogao imati nesagledive posljedice”, Jutarnji list, 13. siječnja 2020.).

117 Izvrstan primjer takvog kriminalno političkog smirivanja emotivno nabijenih javnih i medijskih rasprava putem besmislenih normativnih mehanizmima kaznenog prava je primjerice uvođenje čl. 184j "Kaznena djela iz grupa" (njem. Straftaten aus Gruppen) u njemački Kazneni zakonik. Riječ je o kriminalno političkom odgovoru na raspravu o masovnim seksualnim napadima diljem Njemačke (npr. Köln i Hamburg) u noći uoči Nove godine 2015./2016., kojim je kreirana nova odredba kojom se sankcionira poticanje na činjenje seksualnih delikata kroz samo sudjelovanje u skupini osoba koja drugu osobu navodi na počinjenje kaznenog djela, ako bi član skupine počinio seksualni delikt. Valja se složiti s Bezjak kada novi čl. 184j određuje kao normativni promašaj, koji je, osim toga što je nepotreban, ustavnopravno gledano još i krajnje dvojben. Usporedi: Bezjak, G., Der Straftatbestand des \& 177 StGB (Sexuelle Nötigung; Vergewaltigung) im Fokus des Gesetzgebers, Kritische Justiz, vol. 49, br. 4, 2016., str. 571; Gesetz zur Änderung des Strafgesetzbuches - Verbesserung des Schutzes der sexuellen Selbstbestimmung od 4. studenog 2016. (BGBl. I, str. 2460). Usporedive primjere nalazimo i u domaćem kaznenom zakonodavstvu, ali i onome drugih europskih država, pri čemu se aktualno područje kaznenopravnog uređenja seksualnih delikata pokazalo kao posebno plodno tlo za penalni populizam. 


\section{ZAKLJUČAK}

Tamna brojka kriminala sasvim nedvojbeno predstavlja jedan od ključnih izazova u proučavanju i progonu te prevenciji kažnjivih ponašanja. Riječ je o svojevrsnoj tamnoj strani tamne brojke kriminala i dobro poznatom znanstvenom i praktičnom problemu zbog kojega su kriminološke spoznaje o kriminalu u većoj ili manjoj mjeri fragmentarne i spekulativne, dok je kazneni progon krajnje selektivan i primarno usredotočen na one vrste delikata koje su žrtve i svjedoci spremniji prijaviti nadležnim tijelima. Kriminološka istraživanja nepoznanica, odnosno onih kriminalnih događaja za koje držimo da postoje, iako nisu službeno registrirani kao kriminalni, nastoje rasvijetliti tamnu brojku kriminala te se nerijetko ističe kako upravo takva istraživanja u boljoj mjeri oslikavaju realno stanje kriminala, negoli podaci o registriranom kriminalu. No, kako i studije tamne brojke kriminala pate od vlastitog problema tamne brojke, ali i niza konceptualnih i metodoloških nedostataka, (zasada) ne postoji instrumentarij kojim bismo ostvarili točan i provjerljiv uvid u realnost kriminala. Stoga nam i u kazneno(pravno)j znanosti i praksi trenutačno ne preostaje ništa drugo negoli kombinirana analiza podataka o (ne)registriranom kriminalu iz što većeg broja različitih izvora te njihova interpretacija i konzumacija s određenom dozom opreza.

Osim ove tamne strane, tamna brojka kriminala ima i svijetlu stranu, koja se ogleda u tzv. preventivnom učinku neznanja, a to neznanje je prema Popitzu nužan uvjet funkcioniranja društva u cjelini, ali i održivosti zamišljene generalno preventivne svrhe kaznenoga prava. Naime, kada bismo znali za sva bezbrojna kršenja normi, do kojih dolazi svakodnevno i u svim slojevima društva, tada norme više ne bi imale važenje norme, tj. u biti više ni ne bi bile norme. $U$ tom smislu tamna brojka kriminala nije problem s isključivo negativnim učinkom, već svojevrstan blagoslov neznanja s izrazito pozitivnom funkcijom stabilizacije normi. Osim što brojna sociološka i kriminološka istraživanja daju uporište Popitzovoj tezi, nalazi nedavno provedene eksperimentalne studije upravo Popitzove specifične teze potvrđuju kako rasvjetljavanje tamne brojke, odnosno stvaranje "transparentnosti ponašanja", dovodi do većih razmjera kršenja normi. Drugim riječima, kada znamo da i drugi oko nas krše norme, skloniji smo i sami kršenju norme. Riječ je o iznimno vrijednom empirijskom nalazu koji bi i kaznen(opravn)a znanost, ali i praksa, a posebno politika suzbijanja kriminala, trebala na primjeren način unijeti u emotivno i senzacionalistički nabijenu javnu i medijsku raspravu o kriminalu.

Kriminal je suviše kompleksan, permanentan, omniprezentan i poguban društveni fenomen da bismo o njemu vodili bilo kakve druge rasprave osim onih uistinu konstruktivnih, nepristranih i na (više ili manje spekulativnim) 
spoznajama utemeljenih. Dužnost kriminologije nije "samo" spoznajno rasvjetljavanje (ne)registriranog kriminala i njegove tamne brojke, već i argumentirano unošenje što veće doze razboritosti u znanstveni, praktični, javni i medijski, ali i kriminalnopolitički diskurs o kriminalu. Ako će dio pitanja koja smo postavili i po koji od nalaza i argumenata koje smo iznijeli tome doprinijeti, svrha je ovog rada ispunjena.

\section{LITERATURA}

Aebi, M. et al., European Sourcebook of Crime and Criminal Justice Statistics 2014 Fifth edition 2nd revised printing, European Institute for Crime Prevention and Control HEUNI, Helsinki, 2017.

http://wp.unil.ch/europeansourcebook/files/2018/03/Sourcebook2014_2nd_revised_printing_edition_20180308.pdf (28. kolovoza 2020.).

Ajduković, M., Razvoj i mogućnosti upotrebe samoiskaza kao izvora podataka o delinkventnom ponašanju, Zbornik Pravnog fakulteta u Zagrebu, vol. 38, br. I, 1988., str. $65-82$.

Ajduković, M. et al., Epidemiološko istraživanje prevalencije i incidencije nasilja nad djecom u obitelji u Hrvatskoj, Ljetopis socijalnog rada, vol. 19, br. 3, 2012., str. $367-412$.

Ajduković, M.; Ogresta, J.; Sušac, N., Prikaz konferencije Raširenost nasilja nad djecom u obitelji i među vršnjacima, Ljetopis socijalnog rada, vol. 19, br. 1, 2012., str. $181-186$.

Ariel, B.; Bland, M., Is Crime Rising or Falling? A Comparison of Police-Recorded Crime and Victimization Surveys, u: Deflem, M.; Silva, D.M.D. (ur.), Methods of Criminology and Criminal Justice Research, Sociology of Crime, Law and Deviance, vol. 24, Emerald Publishing Limited, Howard House, 2019., str. 7 - 31. doi:10.1108/S1521-613620190000024004

Bezić, R., Juvenile Delinquency in the Balkans: A Regional Comparative Analysis of the ISRD3-Study Findings, u: Getoš Kalac, A.-M.; Albrecht, H.-J.; Kilchling, M. (ur.), Mapping the Criminological Landscape of the Balkans, A Survey on Criminology and Crime with an Expedition into the Criminal Landscape of the Balkans, Max-Planck-Gesellschaft zur Förderung der Wissenschaften e.V. in coop. with University of Zagreb - Faculty of Law and Duncker \& Humblot, Berlin, 2014., str. 429 - 446.

Bezić, R., Juvenile Delinquency in the Balkans: A Regional Comparative Analysis Based on the ISRD3-Study Findings, Max-Planck-Gesellschaft zur Förderung der Wissenschaften e.V. in coop. with University of Zagreb - Faculty of Law and Duncker \& Humblot, Berlin, u tisku 2020. 
Bezjak, G., Der Straftatbestand des § 177 StGB (Sexuelle Nötigung; Vergewaltigung) im Fokus des Gesetzgebers, Kritische Justiz, vol. 49, br. 4, 2016., str. 557 - 571. doi: 10.5771/0023-4834-2016-4-557

Biderman, A.D.; Reiss, A.J., On Exploring the "Dark Figure" of Crime, The ANNALS of the American Academy of Political and Social Science, vol. 374, br. 1, 1967. str. 1 - 15. doi: 10.1177/000271626737400102

Bobetić, M. et al., Istraživanje tamne brojke delinkventnog i devijantnog ponašanja osoba do 18. godine života, Hrvatska revija za rehabilitacijska istraživanja, vol. 40, br. 2, 2004., str. $219-230$.

Bowles, R.; Reyes, M.G.; Garoupa, N., Crime reporting decisions and the costs of crime, European journal on criminal policy and research, vol. 15, br. 4., 2009., str. 365 - 377. doi: 10.1007/s10610-009-9109-8

Brame, R., Quantitative criminology, u: Miller, J.M. (ur.), 21st Century Criminology: a Reference Handbook, Sage, Thousand Oaks, 2009., str. 437 - 446. doi: $10.4135 / 9781412971997$

Capan, M.; Sindik, J., Zadovoljstvo životom i viktimizacija kod policijskih službenika, Policija i sigurnost, vol. 23, br. 4, 2014., str. 297 - 310.

de Castelbajac, M., Brooding Over the Dark Figure of Crime: The Home Office and the Cambridge Institute of Criminology in the Run-up to the British Crime Survey, The British Journal of Criminology, vol. 54, br. 5, 2014., 928 - 945. doi:10.1093/ bjc/azu047

Derenčinović, D., Prilog raspravi o rasvjetljavanju velike "tamne brojke” kod korupcijskih kaznenih djela, u: Mlinarević, M. (ur.), Korupcija - pojavni oblici i mjere za suzbijanje, Inženjerski biro, Zagreb, 2008., str. 172 - 185.

Diekmann, A.; Przepiorka, W.; Rauhut, H., Die Präventivwirkung des Nichtwissens im Experiment, Zeitschrift für Soziologie, vol. 40, br. 1, 2011., str. 74 - 84. doi: 10.1515/zfsoz-2011-0105

Doorewaard, C., The dark figure of crime and its impact on the criminal justice system, Acta Criminologica: Southern African Journal of Criminology, vol. 27, br. 2, 2014., str. 1 - 13 .

Enzmann, D. et al., A global perspective on young people as offenders and victims, Springer, Berlin, 2018. doi:10.1007/978-3-319-63233-9

European Union, EU guidelines for the International Classification of Crime for Statistical Purposes - 2017 edition, Publications Office of the European Union, Luxembourg, 2017. doi:10.2785/82709

European Union Agency for Fundamental Rights, Violence against women, An EU-wide survey: main results, Publications Office of the European Union, Luxembourg, 2015. doi:10.2811/981927 
Fohring, S., Putting a Face on the Dark Figure: Describing Victims Who Don't Report Crime, Temida, vol. 17, br. 4, str. 3 - 18. doi: 10.2298/TEM1404003F

Getoš, A.-M., Mjesto i uloga kriminologije i viktimologije u Hrvatskoj i u međunarodnom kontekstu, u: Turković, K.; Maršavelski, A.; Roksandić Vidlička, S. (ur.), Liber Amicorum Zvonimir Šeparović: Od kaznenog prava do viktimologije, Zbornik radova u čast 80. rođendana profesora emeritusa Zvonimira Šeparovića, Pravni fakultet Sveučilišta u Zagrebu, Zagreb, 2009., str. 119 - 140.

Getoš Kalac, A.-M., Mapping the Criminological Landscape of the Balkans, u: Getoš Kalac, A.-M.; Albrecht, H.-J.; Kilchling, M. (ur.), Mapping the Criminological Landscape of the Balkans, A Survey on Criminology and Crime with an Expedition into the Criminal Landscape of the Balkans, Max-Planck-Gesellschaft zur Förderung der Wissenschaften e.V. in coop. with University of Zagreb - Faculty of Law and Duncker \& Humblot, Berlin, 2014., str. 23 - 55.

Getoš Kalac, A.-M., Guilt, Dangerousness and Liability in the Era of Pre-Crime - the Role of Criminology? To Adapt, or to Die, that is the Question!, Monatschrift für Kriminologie und Strafrechtsreform, vol. 103, br. 3, 2020., str. 198 - 207. doi: 10.1515/msk-2020-2054

Getoš Kalac, A.-M.; Bezić, R., Criminology, crime and criminal justice in Croatia, European Journal of Criminology, vol. 14, br. 2, 2017., str. $242-266$. doi:10.1177/1477370816648523

Getoš, A.-M.; Giebel, S., Strah od kriminala među studentima Pravnog fakulteta u Splitu, Zbornik radova Pravnog fakulteta u Splitu, vol. 49, br. 3, 2012., str. $533-552$.

Getoš, A.-M.; Giebel, S., Perceptions of fear of crime and punitivity among university students in Croatia, u: Kury, H.; Winterdyk, J. (ur.), Fear of Crime and Punitiveness: Results from International Student Surveys, Universitätsverlag Brockmeyer, Bochum, 2013., str. 105 - 138.

Getoš Kalac, A.-M.; Roksandić Vidlička, S.; Burić, Z., Victimology, Victimisation (Typology) \& Victim Protection in Croatia, u: Meško, G.; Sárik, E.; Getoš Kalac, A.-M. (ur.), Mapping the Victimological Landscape of the Balkans: A Regional Study on Victimology and Victim Protection with a Critical Analysis of Current Victim Policies, Max-Planck-Gesellschaft zur Förderung der Wissenschaften e.V. in coop. with University of Zagreb - Faculty of Law and Duncker \& Humblot, Berlin, 2020., str. $223-276$.

Jackson, J. et al., Just authority? Trust in the police in England and Wales, Routledge, Abingdon, 2012. doi: 10.2139/ssrn.2034343

Kivivuori, J., Discovery of Hidden Crime, Self-Report Delinquency Surveys in Criminal Policy Context, Oxford University Press, Oxford, 2011. 
Korsell, L.E., Big stick, little stick: Strategies for controlling and combating environmental crime, Journal of Scandinavian Studies in Criminology and Crime Prevention, vol. 2, br. 2, 2001., str. 127 - 148. doi: 10.1080/140438501753737615

Kunz, K.-L., Die wissenschaftliche Zugänglichkeit von Kriminalität, Ein Beitrag zur Erkenntnistheorie der Sozialwissenschaften, VS Verlag für Sozialwissenschaften, Wiesbaden, 2008. doi: 10.1007/978-3-8350-5547-6

Kunz, K.-L., Unentdeckte Straftaten aus konstruktivistischer Sicht - ein Beitrag zum Verständnis des Dunkelfeldes, Monatsschrift für Kriminologie und Strafrechtsreform, vol. 103, br. 2, 2020., str. 150 - 157. doi: 10.1515/mks-2020-2045

Kury, H.; Winterdyk, J. (ur.), Fear of Crime and Punitiveness: Results from International Student Surveys, Universitätsverlag Brockmeyer, Bochum, 2013.

Linde, A.; Aebi, M.F., Les enquestes de victimització com a instrument de mesura de la delinqüència $i$ de la inseguretat, u: Murrià-Sangenis, M.; SobrinoGarcés, C.; González-Murciano, C. (ur.), 30 Anis de l'Enquesta de Victimizació de l’Àrea Metropolitana de Barcelona: Vigència $i$ ús de les enquestes de seguretat a les metròpolis, Institut d'Estudis Regionals i Metropolitans de Barcelona, Barcelona, 2020., str. $79-92$.

Maxfield, M.G.; Babbie, E.R., Research methods for criminal justice and criminology, 7th Edition, Cengage Learning, Boston, 2014.

Morgan, R.E.; Oudekerk, B.A., Criminal Victimization 2018, U.S. Department of Justice, Office of Justice Programs, Bureau of Justice Statistics, s.l., 2019.

Nikolaidis, G. et al., Lifetime and past-year prevalence of children's exposure to violence in 9 Balkan countries: the BECAN study, Child and adolescent psychiatry and mental health, vol. 12, br. 1, 2018., str. 1 - 15. doi:10.1186/s13034-017-0208-x

Penney, T.L., Dark figure of crime (problems of estimation), The encyclopedia of criminology and criminal justice, John Wiley \& Sons, Inc., Hoboken, 2014., str. 1 - 6. doi: 10.1002/9781118517383.wbeccj248

Piquero, A.R.; Farrington, D.P.; Blumstein, A., Key Issues In Criminal Career Research, Cambridge University Press, Cambridge, 2007. doi: 10.1017/ CBO9780511499494

Podgor, E.S.; Israel, J.H., White collar crime in a nutshell, 4th Edition, West Academic Publishing, St. Paul, 2009.

Popitz, H., Über die Präventivwirkung des Nichtwissens (1968), Mit einer Einführung von Fritz Sack und Hubert Treiber, Berliner Wissenschafts-Verlag, Berlin, 2003.

Popitz, H., Über die Präventivwirkung des Nichtwissens, Dunkelziffer, Norm und Strafe, u: Klimke, D.; Legnaro, A. (ur.), Kriminologische Grundlagentexte, Springer VS, Wiesbaden, 2016., str. 33 - 46. doi: 10.1007/978-3-658-06504-1_3 
Riedel, M.; Regoeczi, W.C., Missing Data in Homicide Research, Homicide Studies, vol. 8, br. 3, 2004., str. 163 - 192. doi: 10.1177/1088767904265447

Rusac, S., Nasilje nad starijim osobama u obitelji na području grada Zagreba, Ljetopis socijalnog rada, vol. 16, br. 3, 2009., str. 573 - 594.

Silverman, B., Modern Slavery: an Application of Multiple Systems Estimation, Home Office, London, 2014. https://www.gov.uk/government/publications/modern-slavery-anapplication-of-multiple-systems-estimation (16. rujna 2020.).

Sudman, S.; Bradburn, N.M., Effects of time and memory factors on response in surveys, Journal of the American Statistical Association, vol. 68, br. 344, 1973., str. 805 - 815. doi: 10.1080/01621459.1973.10481428

Šeparović, Z.; Turković, K., Žrtve zločina u Hrvatskoj: međunarodni projekt istraživanja žrtava zločina, Hrvatski ljetopis za kazneno pravo i praksu, vol. 4, br. 2, 1997. str. 541 - 565.

Till-Tentschert, U., FRA's work on gender based violence, European Union Agency for Fundamental Rights, Prag, 14. studenog 2017. https://rm.coe.int/fra-presentation-prague-14-november-2017/168076867b (25. kolovoza 2020.)

United Nations Office on Drugs and Crime, International Classification of Crime for Statistical Purposes, Version 1.O, United Nations Office on Drugs and Crime, Beč, 2015.

United Nations Interregional Criminal Justice Research Institute, EU ICS Working Paper Series: Methodology of the European Crime and Safety Survey, Gallup Europe, Bruxelles, 2007.

United Nations Office on Drugs and Crime, Corruption in Croatia: Bribery as experienced by the population, United Nations Office on Drugs and Crime, Beč, 2011. https://www.unodc.org/documents/data-and-analysis/statistics/ corruption/Croatia_corruption_report_web_version.pdf (28. kolovoza 2020.).

Van Dijk, J.J.M., Illuminating The Dark Figure of Crime: Victimisation Surveys and Beyond, Criminology in Europe, vol. 15, br. 3, 2016., str. 4 - 9. https://escnewsletter.org/sites/escnewsletter.org/files/newsletter/2016/esc_2016_3_online_final.pdf (10. kolovoza 2020.).

Van Dijk, J.J.M. et al., The burden of crime in the EU: A comparative analysis of the European Survey of Crime and Safety (EU ICS 2005), Gallup Europe, Bruxelles, 2007.

Van Dijk, J.J.M.; Van Kesteren, J.; Smit, P., Criminal Victimisation in International Perspective, Key findings from the 2004-2005 ICVS and EU ICS, Bibliotheek WODC, Den Haag, 2007. doi: 10.15496/publikation-6621 
Vela Vrabec, N., Nasilje nad starijim osobama, ružna strana društva, Narodni zdravstveni list, br. 626-627, 2012., str. 16 - 18. http://www.zzjzpgz.hr/nzl/74/ nzl_3_4_2012.pdf (25. kolovoza 2020.).

Victim Support Europe, Cross-border Victimisation, Challenges and solutions with respect to the provision of support to victims of crime in a cross-border situation, s.l.a.n. https:/victimsupport.eu/activeapp/wp-content/uploads/2017/02/VSE-Cross-border-Victimisation-Report.pdf (25. kolovoza 2020.).

Wehinger, F., Illegale Märkte: Stand der sozialwissenschaftlichen Forschung, MaxPlanck-Institut für Gesellschaftsforschung, Cologne, 2011. https://www.mpifg. de/pu/workpap/wpl 1-6.pdf (1. rujna 2020.).

\section{MREŽNI IZVORI}

Esanum, Studie zeigt große Mängel bei Leichenschau: Mit dem Messer im Rücken ins Krematorium?, 4. prosinca 2017. www.esanum.de/today/posts/mediziner-fordern-bessere-leichenschau (16. rujna 2020.).

EU Open Data Portal, Special Eurobarometer 464b: Europeans' attitudes towards security, Directorate-General for Communication, s.l., 12. prosinca 2017. https://data. europa.eu/euodp/en/data/dataset/S1569_87_4_464B_ENG (1. rujna 2020.).

Gesetz zur Änderung des Strafgesetzbuches - Verbesserung des Schutzes der sexuellen Selbstbestimmung od 04. studenog 2016. (BGBl. I str. 2460), stupio na snagu 10. studenog 2016, dostupno pod: https://www.bgbl.de/xaver/bgbl/start.xav?startbk $=$ Bundesanzeiger_BGBl\&jumpTo=bgbll 16s2460.pdf (28. rujna 2020.)

Hina, Stručnjaci o podršci trostrukom ubojici: "Riječ je o fenomenu koji je u dva dana poprimio tolike razmjere da bi mogao imati nesagledive posljedice", Jutarnji list, 13. siječnja 2020. https://www.jutarnji.hr/vijesti/hrvatska/strucnjaci-o-podrsci-trostrukom-ubojici-rijec-je-o-fenomenu-koji-je-u-dva-dana-poprimio-tolike-razmjere-da-bi-mogao-imati-nesagledive-posljedice-9848836 (1. rujna 2020.).

Mladiće osumnjičene za grupno silovanje maloljetne Zadranke dovode u zatvor: pogledajte snimku privođenja, Net.hr, 17. listopada 2019. https://net.hr/danas/crna-kronika/ pritisak-je-urodio-plodom-zadarski-sud-donio-odluku-o-istraznom-zatvoru-za-mladice-osumnjicene-za-grupno-silovanje-maloljetnice/ (1. rujna 2020.).

Podgornik, B., Podaci OECD-a: Ubrzava se iseljavanje iz lijepe naše - u dvije godine iz Hrvatske odselilo 138 tisuća ljudi, Novi list, 13. kolovoza 2017. https://www. novilist.hr/vijesti/hrvatska/ubrzava-se-iseljavanje-iz-lijepe-nase-u-dvije-godine-iz-hrvatske-odselilo-138-tisuca-ljudi/ (1. rujna 2020.).

T.A., Nasilnici iz Kaštela: Policija objavila detalje odvratnog zlostavljanja koje je užasnulo Hrvatsku, Dnevnik, 31. kolovoza 2020. https://dnevnik.hr/vijesti/crna-kroni- 
ka/policija-objavila-detalje-zlostavljanja-mladica-u-kastel-stafilicu---618511. html (1. rujna 2020.).

Universität Rostock, Die meisten Todesbescheinigungen weisen Fehler auf: Studie der Uni Rostock bringt erschreckende Fakten ans Tageslicht, 1. rujna 2017. www.uni-rostock.de/universitaet/kommunikation-und-aktuelles/medieninformationen/ detailansicht/n/die-meisten-todesbescheinigungen-weisen-fehler-auf-16349/ (16. rujna 2020.). 
Summary

Anna-Maria Getoš Kalac*

Dalia Pribisalić**

\section{THE DARK AND THE BRIGHT SIDE OF THE DARK FIGURE OF CRIME: ON THE CHALLENGES OF RESEARCHING THE UNKNOWN AND THE BLISS OF IGNORANCE}

In the paper at hand the authors critically analyse the state of the art in the research into the dark figure of crime, as well as the conceptual and methodological challenges that are inherent to this kind of research. They do so based on current international, foreign and domestic studies, with the goal of highlighting not only the commonly stressed 'dark side' of the dark figure of crime, but also in order to raise awareness of its almost completely disregarded 'bright side'. In this regard the bright side of the dark figure of crime relates to the thesis of the so-called preventive effect of ignorance (germ. Präventivwirkung des Nichtwissens) and presents a phenomenon with a vastly important positive function which has thus far been completely neglected in the domestic criminological and criminal law discourse. This function basically ensures that the criminal justice response to criminal behaviour is perceived as comprehensive and effective. Without such perception the general preventive effect, as envisaged by criminal law, would be unsubstantial. By highlighting the dark figure's bright side, the authors on the one hand aspire to make a scientific contribution to the comprehensiveness of the discourse about the dark figure of crime in Croatia, while on the other hand they illustrate the unsolvable conceptual and almost unavoidable methodological challenges which are inherent to the attempts of shedding light upon the dark figure of crime. The authors' intention is neither to devalorize dark figure research in general, nor to bring about resignation with regard to enterprises seeking to reveal the dark figure of certain types of crime by means of victimisation or self-report studies. It is rather the intention of the authors to comprehensively and critically examine the dark figure phenomenon in all its complexity, vividness and mutual interwovenness with the criminal justice actors, and while doing so to neither underestimate the dark figure's negative cognitive effects, nor to ignore its overly positive function in the service of norm stabilisation and sustaining the repressive system, as well as society as a whole.

Keywords: dark figure of crime, victimisation surveys, measuring crime, self-report delinquency studies

* Anna-Maria Getoš Kalac, Ph. D., Associate Professor, Faculty of Law, University of Zagreb, Trg Republike Hrvatske 14, 10000 Zagreb, Croatia; agetos@pravo.hr;

ORCID ID: orcid.org/0000-0002-0016-764X

** Dalia Pribisalić, mag. psych., Assistant, Faculty of Law (Violence Research Lab), University of Zagreb, Trg Republike Hrvatske 14, 10000 Zagreb, Croatia; dpribisalic@pravo.hr;

ORCID ID: orcid.org/0000-0001-5155-9793 